\title{
Structural controls on the hydrogeological functioning of a floodplain
}

\author{
Simon Martin ${ }^{1} \cdot$ Stefan Klingler $^{1} \cdot$ Peter Dietrich $^{1,2} \cdot$ Carsten Leven $^{1}\left(\mathbb{D} \cdot\right.$ Olaf A. Cirpka $^{1}$
}

Received: 28 April 2020 / Accepted: 4 August 2020 / Published online: 22 August 2020

(C) The Author(s) 2020

\begin{abstract}
Floodplains are often conceptualized as homogeneous sediment bodies which connect streams with their respective catchment and buffer agricultural inputs. This has led to a general bias within the hydrological community towards research on sites where the floodplain is a clear conduit for groundwater flow. In humid temperate regions of central Europe, floodplains have experienced rapid environmental changes since the last glaciation, yielding significant bedrock weathering and predominantly finegrained, highly stratified hillslope and floodplain sediments. Such heterogeneous sedimentary architecture leads to conceptual ambiguities in the interpretation of the hydrogeological functioning of floodplains, thus raising the question: Do floodplains act as barriers or conduits to groundwater flow? This study analyzes the Ammer floodplain close to Tübingen in south-western Germany as a representative mid-section floodplain in a temperate climate where the regional bedrock-geology is dominated by mudstones. Geological, geophysical, and geochemical characterization and monitoring techniques were combined to shed light on the internal geological structure as a key control modulating the floodplain hydrology. Two partially separate groundwater systems were identified: a gravel body at the bottom of the Quaternary sediments and a Holocene confined tufaceous aquifer, separated by low-permeability clays. Despite flow being predominantly along-valley, sulfate concentrations in the floodplain aquifers showed evidence of a strong connection to the gypsum-bearing hillslope, particularly where tributary valley sediments are present (e.g., alluvial fans). Results from a floodplain water balance suggest the hillslope- and floodplain-aquifer material act as a barrier to hillslope groundwater recharge, where a large fraction may be bypassing the local floodplain groundwater system.
\end{abstract}

Keywords Groundwater flow $\cdot$ Conceptual models $\cdot$ Floodplain $\cdot$ Sedimentary architecture $\cdot$ Biogeochemical turnover

\section{Introduction}

Floodplains connect rivers with their catchments via groundwater pathways. The hydrological functioning of floodplains exerts a strong control on the timing and magnitude of streamflow generation (Jencso and McGlynn 2011), flood wave propagation (Pinder and Sauer 1971), and stream-ecosystem behavior (Jacobs and Gilliam 1985). In addition, floodplain sediments often exhibit a high electron donating capacity in

Carsten Leven

carsten.leven-pfister@uni-tuebingen.de

1 Center for Applied Geoscience, University of Tübingen, Schnarrenbergstr. 94-96, 72076 Tübingen, Germany

2 Helmholtz Center for Environmental Research GmbH-UFZ, Department of Monitoring and Exploration Technologies, Permoserstrße 15, 04318 Leipzig, Germany combination with subsurface residence times that yield favorable redox conditions for biogeochemical turnover of nutrients and degradation of oxidized contaminants, so that they provide a critical environmental filter function in agricultural landscapes, affected by surplus nitrate inputs (Burt et al. 1999; Hill 2019; Vidon et al. 2019).

In humid temperate regions of central Europe, floodplains have experienced rapid environmental changes since the last glaciation, through the Holocene warming, until the present time. Floodplain sediments reflect the changes of climate and land-use in their strata of fine-grained and coarser material, originating from the surrounding hillslopes, being deposited by the river, or being precipitated in-situ as autochthonous sediments. Characteristically, floodplain-aquifer materials are highly heterogeneous in their hydraulic and biogeochemical properties. This geological complexity leads to conceptual ambiguities in the interpretation of the hydrological functioning of floodplains, which also results in high uncertainty 
regarding their relevance as modulators of catchment-scale biogeochemical turnover.

Within the hydrology community, previous work has made significant progress to improve understanding of the hydrological processes within floodplains, with a specific focus on headwater and lowland settings. In such settings, perturbations induced by climatic forcings activate various flowpaths, and competing conceptual models have been put forward to explain the numerous observed hydrological responses (Hill 1990; Buttle 1994; Kirchner 2003; Jung et al. 2004; Brantley et al. 2017).

Figure 1 illustrates conceptual models of a floodplain with detail of the varying degrees of hydrogeological functioning. Typically, rivers and their adjoining floodplains are considered integrators of groundwater flow paths (left side of Fig. 1), implicitly treating the catchment as a closed hydrological system (Fan 2019). Furthermore, topographic indices are often used to subdivide catchments into different hydrological response units, which may be conceptualized as bucket-type elements without any internal heterogeneity (Devia and Ganasri 2015). Unfortunately, in many geological settings, the spatially variable, but nonrandom, sedimentary architecture can complicate the hydrological functioning (right side of Fig. 1). One possible complication lies in interbasin groundwater flow, hampering the formulation of the water balance of a catchment (Fan 2019). A second complication could be that preferential flow paths or low-permeability layers may disconnect surface and subsurface flowpaths, leading to decoupled catchments (Brunner et al. 2009). Such structure-induced complications could not only significantly impact the hydrological functioning of a floodplain, but also associated soluteturnover processes.

Over the last 30 years, research on the riparian zone has been focused on linking the prevailing floodplain hydrological conditions to the biogeochemical cycling of nutrients (Hill 1990, 2019; Burt et al. 1999; Clément et al. 2003; Burt and Pinay 2005; Pfeiffer et al. 2006; Tesoriero and Puckett 2011; Yabusaki et al. 2017; Vidon et al. 2019). In temperate floodplains, the high content of organics, along with significant sediment stratification, results in a high degree of heterogeneity with respect to biogeochemical properties (right of Fig. 1). Regions of enhanced reactivity characteristically occur at interfaces of subsurface depositional features (Hill et al. 2004; Kolbe et al. 2019; Kim et al. 2019) or of different landscape elements such as the hillslope-floodplain (Clément et al. 2003) and near-stream interfaces (Vidon et al. 2010). However, with respect to catchment-scale solute processing, the relevance of a reactive subsurface region depends on the strength of groundwater flow passing through it, which, in turn, is controlled by the hydraulic properties and boundary conditions of the subsurface.

In studies on floodplain and catchment hydrology, the relevance of the geological structure is considered in variable degrees of detail (Devito et al. 2000; Duval and Hill 2006; Schilling and Jacobson 2012; Karan et al. 2013; Hale and McDonnell 2016; Hale et al. 2016; Pfister et al. 2017; Ó Dochartaigh et al. 2019), with a general bias towards research on sites with a shallow soil cover above impermeable bedrock or highly transmissive floodplain sediments in hydraulic contact with the draining water body (Hill 2019).

The climatic and geological settings, both bedrock and surficial, are known to control the morphology of a catchment, as well as the regional-, intermediate- and local-scale groundwater flow (Devito et al. 2005; Duval and Waddington 2018). Net groundwater gains and losses of a catchment can lead to large errors in water and solute budgets if catchment boundaries are derived from topography alone (Larkin and Sharp 1992; Devito et al. 2005; Bloomfield et al. 2011; Fan 2019).
Fig. 1 Conceptual model of floodplains. Front face: simplified conceptual floodplain function with topography-driven flow through a medium of organic-rich floodplain sediments. Side face: hydrogeological model where groundwater flowpaths are controlled by the subsurface architecture of sediments

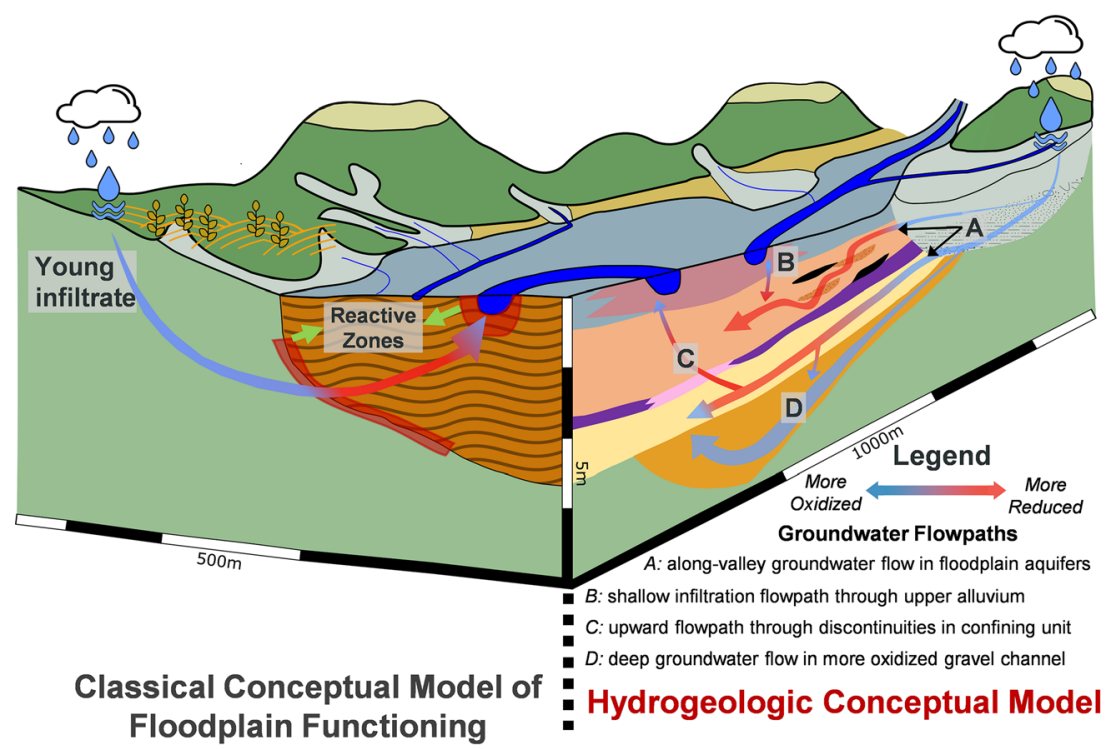


Additionally, within river midsections where the potential of bedrock weathering is high, it is common to find wide, thick and highly stratified floodplains, with fine-grained (often Holocene) sediments prevailing over highly permeable (often Pleistocene) sands and gravels (Haycock et al. 1997; Gibbard and Lewin 2002).

The complex interaction between local floodplain groundwater flow systems and the larger intermediate or regional groundwater flow, along with the high degree of subsurface heterogeneity, highlights an existing knowledge gap in floodplain hydrology, pertaining to temperate settings. The key question is whether floodplains act as barriers or conduits to groundwater flow. In essence, three competing scenarios are considered: (1) The local groundwater systems within the floodplain connect the catchment to the river; (2) groundwater collects the net precipitation in the catchment, but the majority of groundwater bypasses the floodplain via an intermediate- or regional-scale groundwater flow system; or (3) other drainage systems, such as surface tributaries and channels at floodplain boundaries collect the majority of net precipitation in the catchment, and the groundwater flow path through the floodplain is only of minor relevance. To complicate matters in river mid-sections, not all groundwater flow in a floodplain needs to originate from the surrounding hillslopes; substantial contributions may originate from losing river sections or deeper groundwater flow paths.

In this context, it is postulated that the geometry and internal geological structure within a floodplain, and its surrounding landscape, act as major controls on determining the hydrological functioning of a temperate floodplain and thus its relevance to solute processing within the catchment. Specifically, the presence of a continuous and highly transmissive alluvial aquifer, and the associated uncertainty in the hydraulic parameters, will have serious implication for how the floodplain functions. Therefore, there exists a need for continuous, arduous characterization and quantification of floodplain aquifer hydrogeology and the effects of physical transport on (bio)geochemical turnover.

This study analyzes the Ammer floodplain close to Tübingen in south-western Germany as a typical representative for a mid-section floodplain in a temperate setting where the regional bedrock-geology is dominated by mudstones. In a two-stage hydrogeological field study, geological, geophysi$\mathrm{cal}$, and geochemical characterization and monitoring techniques were combined to shed light on the internal geological structure as a key control modulating the floodplain hydrology. Using the Ammer catchment as a temperate analog, a regional-scale site characterization was combined with a series of refined field campaigns to identify and monitor the main hydrogeological units and develop a conceptual hydrogeological model.

\section{Materials and methods}

\section{Study area}

The study area is located within the Ammer catchment in southwest Germany, covering approximately $238 \mathrm{~km}^{2}$ (Fig. 2). The Ammer River runs from its headwaters near Herrenberg over a $22-\mathrm{km}$ distance and $110 \mathrm{-m}$ elevation change towards its outlet east of Tübingen, confluencing with the Neckar River, a tributary to the Rhine River. Its discharge (annual average $\approx 1 \mathrm{~m}^{3} / \mathrm{s}$ ) is mainly fed by karstic limestone springs and a waste-water treatment plant, which also has a strong control on the river-water chemistry (Schwientek et al. 2013). The Ammer catchment has a warm and temperate climate with precipitation occurring throughout the year. During the winter months the rainfall is relatively persistent, whereas summer precipitation is characterized by more episodic events, which approximately account for $70 \%$ of the mean annual rainfall of $750 \mathrm{~mm}$. Agricultural land dominates the surface cover of the Ammer catchment, with approximately $70 \%$ of the land cover, whereas the hilltops are mostly covered by forest. The regional geology of the Ammer catchment is typical for central Europe (Burt et al. 2002; Grathwohl et al. 2013). The Ammer catchment is located within the Southwest German Escarpment where the main bedrock strata are tilted $\approx$ $3^{\circ}$ towards the southeast (Geyer and Gwinner 2011). The catchment is characterized by a hilly topography with hillslopes and escarpments up to $150 \mathrm{~m}$ above the river. The Triassic bedrock consists of the Middle Triassic Muschelkalk outcropping in the western part of the catchment and Upper Triassic Keuper units covering the eastern part of the catchment and the hills. The study site is located in the eastern part where the confining lower Keuper strata of the Erfurt formation separate the aquifers in the Quaternary floodplain sediments and the aquifer in the weathered bedrock of the Grabfeld formations from the underlying karstic Muschelkalk aquifer.

The Ammer floodplain under investigation sits downstream of a fault line where the Ammer River leaves the competent Middle Triassic Muschelkalk limestone (northwest of Pfäffingen, Fig. 2) and enters an up to 1,500-m-wide valley cut into the mudstones and dolostones of the lower and middle Upper Triassic Keuper strata. The very flat central part of the floodplain is bounded by steep hills on the north and gently sloping hillslopes on the south leading to a flat saddle in the southwestern part (Wurmlingen Saddle, Fig. 2) and a forested hill in the southeastern part. The surface coverage of this $\sim 5 \mathrm{~km}^{2}$ segment of the Ammer catchment is dominated by agricultural land use and urban structures. Within this subsection of the Ammer catchment, the bedrock changes from west to east. While the dolostones of the Erfurt formation are present in the westernmost part until Pfäffingen, the main floodplain sits on top of the Grabfeld formation, a weathered and 

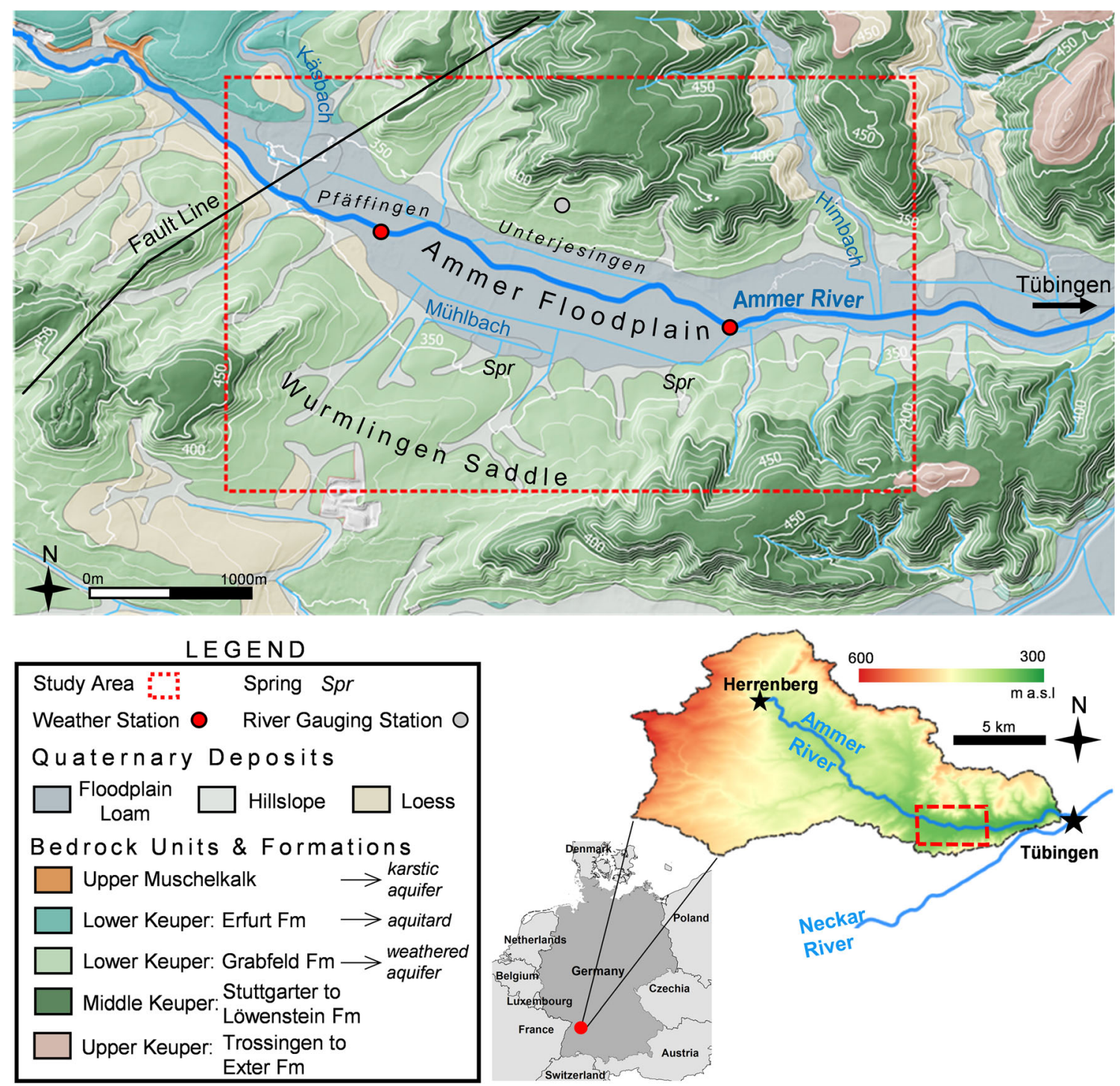

Fig. 2 Location of the field investigation site and regional geologic map

partially karstified gypsum-rich mudstone (Fig. 2). The steep hills consist of the upper four formations of the Middle Keuper with a sequence of more competent sandstones and less competent mudstones and rise up to $140 \mathrm{~m}$ above the central floodplain. Several fan-shaped erosional valleys form a rolling-hill topography along the southern hillslope.

Within the study area, the Ammer River is a third-order stream, running eastwards towards Tübingen, where this modern river stretch was channelized first downstream of Unterjesingen in the fourteenth and fifteenth century, and then again in the twentieth century in the direct vicinity of the town for milling purposes (Frauendiener 1963; Fig. 2). Smaller, ephemeral streams in the floodplain are fed by springs and discharge through man-made drainage channels such as the main Mühlbach channel. Additionally, tile drains are present in some agricultural plots, even though their locations and status are highly uncertain.

\section{Site characterization}

The hydrogeological site characterization of the floodplain was performed in two stages of field campaigns. The first stage aimed at identifying the main (regional) groundwater flowpaths within the Ammer floodplain (Fig. 2), and assessing their dynamics with a regional monitoring well network. This involved collecting drill cores in a distributed network across a large portion of the floodplain with an average spacing between cores of $280 \mathrm{~m}$ (ranging from $15 \mathrm{~m}$ to $800 \mathrm{~m}$ to the nearest drill core). The main geological structure was described and correlated across the entire study area. Based on the texture and the extensiveness of the geological strata, they were subsequently classified as regional aquifers and aquitards, and instrumented with groundwater monitoring wells. The regional groundwater flow and hydrochemical 
dynamics were monitored with continuous water-level recordings and within groundwater-sampling campaigns.

The second stage of field investigations focused on describing how the floodplain collects water and subsequently transfers it to discharge routes. This necessitated characterizing the structural boundaries between the floodplain aquifers and the adjacent subsurface compartments. The new measurement locations specifically targeted the interfaces between the floodplain aquifer systems and the hillslope, river, and bedrock subsurface compartments. The distributed drill-core and monitoring-well network was extended to the floodplain perimeter, as well as outside the floodplain setting altogether. Newly detected geological features were described based on their texture, and subsequently targeted with groundwater monitoring wells. Monitoring of the groundwater fluctuations, along with groundwater sampling, facilitated identifying the possible origin of groundwater flowpaths within the floodplain system.

\section{Geological and geophysical datasets}

Sedimentary cores were collected both with a sonic drilling unit (SmallRotoSonic SRS T, SonicSampDrill) and a direct push unit (6610 DT, Geoprobe). The depth of the drill cores was limited either by lack of penetration into competent bedrock, or legal regulations from drilling permits. The collected drill cores (51 $\mathrm{mm}$ in diameter) were stored in plastic liners or metal core boxes. Preparation of the cores involved exposing fresh surfaces either by hand, or by freezing the core and subsequently cutting it with a rock saw. The internal structure was described, photographed and grouped into main lithologies. For selected cores, a grain-size analysis was performed. As per German Standard DIN 18123-4, sieve analysis was conducted for the grain sizes greater than $0.063 \mathrm{~mm}$ (coarse fraction), with sedimentation analysis being conducted for the clay- and silt-sized grains (fine fraction). Samples of 100 $200 \mathrm{~g}$ were collected in fixed 50-cm intervals to prevent sampling bias in the vertical profiles of grain-size distribution.

A 550-m long Wenner- $\alpha$ electrical resistivity profile was acquired with $1.5-\mathrm{m}$ electrode spacing across the floodplain (RESECS, DMT-Group). The data were subsequently filtered and inverted with PyBERT to receive a continuous profile of subsurface resistivity distribution and infer layer continuity and boundaries for the geological model (Günther et al. 2006). Based on the inversion result, a spatial geoelectrical mapping of a higher resistive target feature with fixed electrode spacings was conducted, as described by Klingler et al. 2020. Vertical geophysical logging was also performed, including direct-push electrical-conductivity (EC) profiles, direct-push color logging, and logging of natural gamma radiation in boreholes. The logging results mainly confirmed the major stratification of Quaternary floodplain sediments discussed in the following.

\section{Geological modeling}

The geological mapping incorporated hard data from lithofacies picks (both drill core data and vertical gamma profiles), along with regional geological datasets, into the implicit geological modelling software LeapFrog (LeapFrog Works). The depths of the facies contacts were converted to elevations for the purposes of correlation. The boundaries of the geological model, i.e. contact between floodplain sediments and subcropping bedrock units, were defined using the most recent 1:50,000 regional geologic map (LGRB 2012). The model top is taken from topography of the study area by means of a 10-m digital elevation model (LGL 2009). The base of the geological model is the subcropping bedrock, where minimal hard data is available, necessitating the use of polylines within LeapFrog, mimicking typical bedrock valley shapes, to guide the bedrock surface interpretation. LeapFrog invokes implicit modelling in which geological contact surfaces are created by interpolation of observed lithofacies contacts and their orientation. With the ground surface and bedrock topography as the upper and lower boundary of the model, respectively, volumes of the geological units are generated between the sedimentary surfaces, and cross-sections can be generated for any region of the modelling domain.

\section{Monitoring wells and instrumentation}

Monitoring wells were installed by advancing an $83 \mathrm{~mm}$ $\left(3.25^{\prime \prime}\right)$ metal casing (with an expandable tip) to the target depth using a direct push rig, then lowering the assembled monitoring well string before pulling back the metal casing. Monitoring-well materials at the site include $51 \mathrm{~mm}\left(2^{\prime \prime}\right)$ diameter polyvinyl chloride, as well as $25 \mathrm{~mm}\left(1^{\prime \prime}\right)$ and $41 \mathrm{~mm}$ $\left(1.5^{\prime \prime}\right)$ nominal diameter high-density polyethylene well casings. Well screens were completed with a poured sand pack, prepacked sand pack, or by natural formation collapse, which was always followed by a bentonite top seal prior to backfilling the annular space. A flush-mount protective casing was installed at all monitoring wells, with a cement and concrete seal to prevent surface-water infiltration. Monitoring wells were developed using suction pumping and surging methods to improve hydraulic communication to the surrounding sediments disturbed during the process of well installation. The top of the well casing and ground surface were surveyed using a combination of a differential global positioning system and a laser level.

\section{Hydrological, hydrogeological, and hydrochemical datasets}

Figure 2 shows the locations of a weather station in Unterjesingen (LTZ 2020) and a gauging station for Ammer River at Pfäffingen (LUBW 2020). Groundwater level data in monitoring wells were continuously collected with dedicated 
groundwater data loggers (CTD and MicroDiver, Schlumberger Water Services) in 15-min intervals; or, when pressure loggers were not available, measured with a manual water level tape. The measured absolute pressure values were corrected using the barometric pressure from a Baro-Diver approximately $7 \mathrm{~km}$ from the site, in Tübingen. Each pressure-logger dataset was manually reviewed, corrected for obvious errors, and converted to absolute groundwater elevations with the manual water-level readings. Groundwater flow maps were constructed by spatial interpolation of groundwater elevations for a specific timestamp, using ordinary kriging with an omnidirectional linear variogram.

Hydraulic parameters in the vicinity of the monitoring wells were estimated by well testing, including slug tests, drawdown-recovery tests, and multi-well pumping tests, each sampling a different volume of the aquifer. Analysis of the slug and pumping test consisted of type-curve regression fits on the measured displacement time-series with the appropriate analytical solution (HydroSOLVE Inc.): slug tests showing an overdampened water-level response were analyzed using the Bouwer and Rice (1976) or Hyder et al. (1994) analytical solutions, whereas tests with an underdampened (oscillatory) response required the Butler Jr. (1998) analytical solution to fit the data. Late-time recovery data from single-well recovery tests were fit with the Theis Recovery (Theis 1935) method, and drawdown and recovery data from multi-well pumping tests were fit with the Theis (1935) analytical solution.

The monitoring wells were periodically sampled throughout the monitoring period of the study. With a batterypowered peristaltic pump (Eijkelkamp Soil \& Water) all sampled monitoring wells were purged prior to collecting a representative groundwater sample. For all groundwater samples, field-measured parameters were either recorded continuously with a flow-through cell, instrumented with a multi-parameter probe (smarTROLL and Aqua TROLL 500, In-Situ), or from the recovering groundwater level after purging the monitoring well dry. Field-measured parameters included $\mathrm{pH}$, temperature, specific electrical conductivity (EC), dissolved oxygen (DO), and redox potential. Same-day filtered groundwater samples were analyzed for major ion hydrochemistry with ion chromatography (DX-120, Dionex), dissolved organic carbon (HighTOC, Elementar), alkalinity (Titrino Plus, Metrohm), and nitrogen species (AutoAnalyzer $3 \mathrm{HR}$, SEAL Analytical). Due to the instability of ammonium, the nitrogen species were analyzed on the next morning. Bisulfide was analyzed separately (Multiskan GO, Thermo Scientific) for a single sampling event in July 2019, where the samples were stabilized in the field using a zinc acetate solution and frozen as soon as possible. Erroneous results from sampling campaigns were flagged during the review of the hydrochemistry datasets. This process included checking the ion balance and a comparison to the previous hydrochemical datasets. Statistical analysis of the hydrochemical data included reviewing univariate and bivariate distributions, as well as a hierarchical cluster analysis (HCA) using the Euclidean distance (Ward 1963). Prior to the cluster analysis, the cleaned hydrochemical datasets typically required log-transformation, as well as a $\mathrm{z}$ score normalization. As with the groundwater contour map, interpretation of spatial hydrochemical patterns involved interpolation using ordinary kriging, selecting a variogram model to best fit the spatial correlation structure of the hydrochemical parameter.

\section{Results}

Although the site characterization was conducted in two stages, the results are presented without distinction, sorted by the type of datasets.

\section{Geological setting}

In total, 35 cores were drilled to determine the main lithofacies in the sequence of Quaternary unconsolidated sediments, their spatial extent and heterogeneity, and to determine the depth to bedrock. The central floodplain is underlain by the gypsumrich mudstone of the Grabfeld formation (Middle Keuper, Triassic, Fig. 2), the subsequent floodplain lithostratigraphy, from bottom to top is: gray clay-rich gravel, gray silty clay, cream-colored calcareous freshwater tufa with thick peat layers, and an uppermost grayish brown alluvial loam. The layer contacts in the drilling cores were consistent throughout the central floodplain and this sequence of floodplain lithologies is depicted in detail in Fig. 3. Along the hillslopes, the general depth to bedrock decreased, and a reddish-green clayey gravel was identified on top of the bedrock contact. Since drilling cores are costly and time demanding, the geological interpretation was supported with geophysical data from geoelectrical measurements and downhole natural gamma radiation measurements. Finally, all the data were combined in a regional geological model of the Ammer floodplain.

\section{Floodplain and hillslope geology}

Figure 3 presents the central floodplain lithofacies as a standard lithostratigraphic profile including grain size and total organic carbon analysis along with representative photos of drill cores. The average depth to bedrock is $14 \mathrm{~m}$, which is retrieved as a reddish-grayish laminated mudstone in a few cores. Drilling permits and equipment limited the penetration into bedrock, and thus, when there was no bedrock recovery, the lithologic contact was assumed at the maximum drilling depth.

"Gravel" is the lowermost Quaternary lithofacies, which was recovered typically from 11 to $14 \mathrm{~m}$ below ground 
Fig. 3 Profile of the main units in the floodplain. a

Lithostratigraphic units; b grainsize analysis from representative core samples (cG: coarse gravel, $\mathrm{mG}$ : medium gravel, fG: fine gravel, cS: coarse sand, $\mathrm{mS}$ : medium sand, fS: fine sand, fines: clay and silt); $\mathbf{c}$ total organic carbon data of upper floodplain sequence; $\mathbf{d}$ representative core photos of the main floodplain lithology

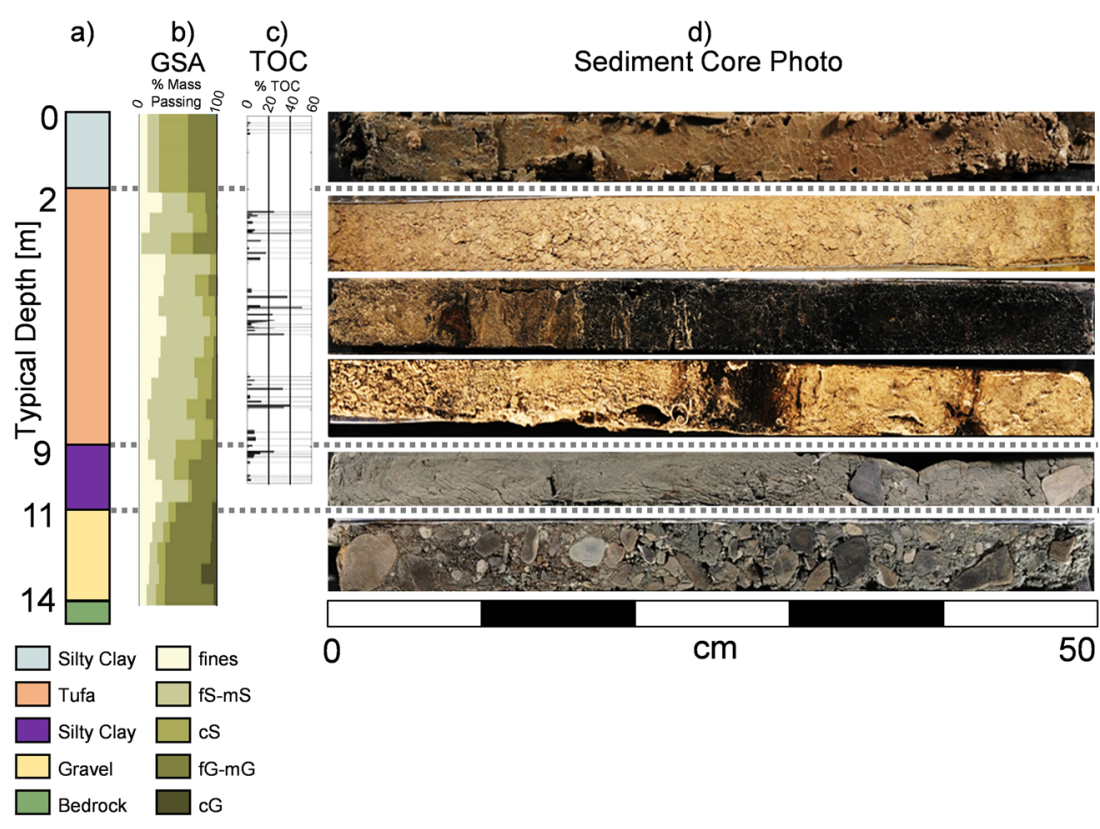

surface, and consists of poorly sorted clasts up to small cobble size within a gray, clayey-silty matrix (Fig. 3d). The coarse fraction is dominated by well-rounded limestone clasts, as well as a few sandstone and mudstone clasts. As the bedrock at the hillslopes contains no limestones, these clasts must have originated from the Middle Triassic Muschelkalk limestone outcrops upstream of Pfäffingen (Fig. 2) and been deposited by the Ammer River. In general, this clast-supported gravel shows no orientation or obvious gradation of clasts and no evidence of vegetation. When encountered, the bottom contact to the bedrock is sharp (Fig. 3g), while the gravel changes gradually upwards into a gray, loamy clay with few very coarse gravel clasts.

The overlying "Lower Clay" lithofacies ranged in thickness from 0.5 to $3 \mathrm{~m}$, with an average depth of $9 \mathrm{~m}$ below ground surface. The dense, plastic clay was moist in the cores and very hard after drying. The top lithological contacts were partially gradational and partially sharp with indication of paleo-exposure in few cores.

The "Tufa" lithofacies is the thickest ( $2-9 \mathrm{~m}$ below ground surface) and most heterogeneous layer in the sedimentary floodplain sequence, and comprises silt to coarse-gravel sized calcareous grains $(0.06-30 \mathrm{~mm})$, which are referred to here as Tufa, with high content of organic matter, $5-50 \%$ fraction of total organic carbon (Fig. 3c), and imbedded peat layers (Fig. 3d). Three subfacies are distinguished based on color, grain size, and the presence of peat. In general, the upper Tufa sequence is fine-grained with very white color and millimeter-sized black organic-carbon specs. The middle section of the Tufa sequence often comprises brown coarsergrained calcareous deposits with grain sizes of $0.2-0.6 \mathrm{~cm}$ with hollow cylindrical nodules and peat inclusions up to $4 \mathrm{~cm}$ as well as abundant plant remnants, and planaspiral and trochospiral gastropodal shells. The Tufa middle section is characteristically cyclic, with each cycle (tens of centimeters) showing gradational changes in color (cream to light brown to dark brown), typically ending with a 5-10-cm-thick peat layer sharply contacting the next cycle. The lowermost section of the Tufa facies was often found to be dominated by dark brown, medium to coarse calcareous sands in a silty matrix. Thicker peat layers are predominantly found in the lower half of the Tufa succession, ranging in thickness from a few centimeters to a meter, with fully preserved and horizontally oriented leaves and wood fragments.

The top $2 \mathrm{~m}$ in the floodplain sequence consist of a very loamy, gray to brown clay with color transitions from lighter to darker brown with depth (Fig. 3c), which are interpreted here as alluvium. In this "Upper Clay" lithofacies, no shells or vegetation were observed and the moisture content was well preserved in the core. In the vicinity of the recent Ammer River course, the Upper Clay is thicker (up to $4 \mathrm{~m}$ ), with evidence of wellrounded medium-sized gravels.

Along the southern fringes of the floodplain a "Hillslope Gravel" lithofacies is present, ranging in thickness from 4 to $13 \mathrm{~m}$, and described as reddish-green clayey gravels with mudstone and sandstone clasts. The oligomictic gravel clasts were mostly edgy and up to $5 \mathrm{~cm}$ in size, indicating a shorter transport distance for the clasts. This poorly sorted lithofacies is highly variable between drilling locations but consistently showed no evidence of limestone clasts, differentiating from the Gravel floodplain lithofacies. Therefore, the authors interpret these clasts as originating from the bedrock of the hillslopes. At locations along the fringes of the floodplain, the hillslopes lithofacies are found in lithological contact with all central floodplain lithofacies. 


\section{Geoelectrical measurements}

The ability to detect geological features and their horizontal continuity by drill cores is limited by their spacing. To fill this gap, the previously presented geological datasets were complemented by geoelectrical surveying. The electrical resistivity tomography (ERT) profile across the floodplain shown in Fig. 4a confirmed the generally continuous layering of the floodplain sediments in the upper $10 \mathrm{~m}$. Below, a relatively higher resistive anomaly of approximately $150 \mathrm{~m}$ width in the center of the floodplain indicates lateral changes in the basal gravel. The dashed white lines in Fig. 4 highlight the suspected outline of the basal-gravel feature, which requires ground-truthing by drill cores for validation. Subsequent drilling into the center of the anomaly revealed a clean gravel section in the lower $5 \mathrm{~m}$ above a $20 \mathrm{~m}$ deep bedrock contact. This higher-resistivity feature could be traced over the distance of about $1 \mathrm{~km}$ by depth-targeted geoelectrical mapping with constant electrode spacing (Klingler et al. 2020). Figure $4 \mathrm{~b}$ presents the results of the geoelectrical mapping with red colors representing higher apparent resistivities in the target depth. This meandering belt of higher apparent resistivities is interpreted as a paleo-channel structure of cleaner gravel bounded by lower-resistive mudstones of the bedrock (in blue in Fig. 4b).

\section{a) Geoelectric Resistivity Inversion Result}

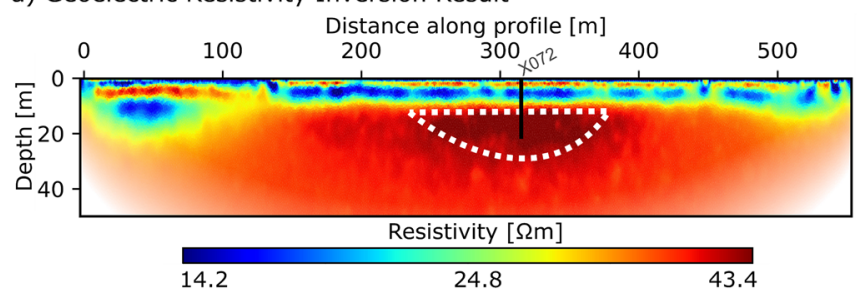

b) Map of Apparent Resistivities

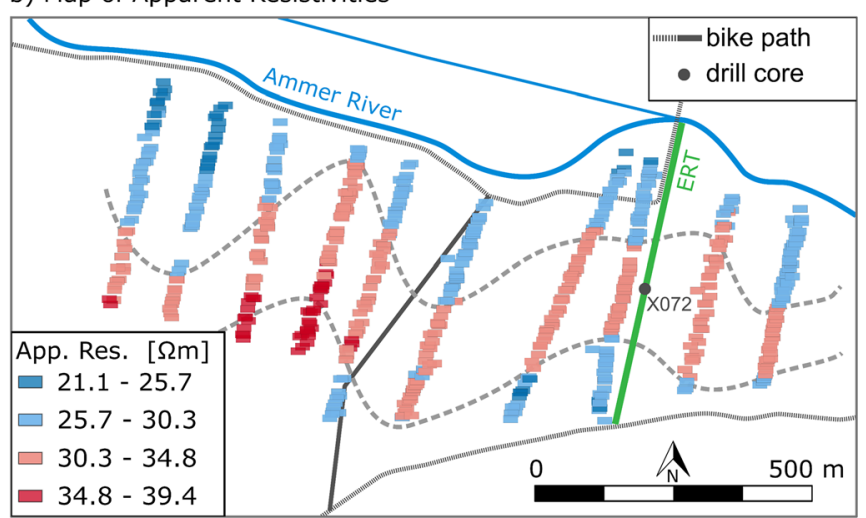

Fig. 4 Results of geoelectrical surveying, adapted from Klingler et al. (2020) with permission from Elsevier. a Inversion result from an electrical resistivity tomogram (ERT) profile across the floodplain; $\mathbf{b}$ results from electrical resistivity mapping showing a meander of higher resistivity material. Location of ERT profile is marked in green

\section{Geological model}

Geological modelling facilitated the visualization of the spatial extent, continuity and thicknesses of the floodplain stratigraphy, incorporating all geological and geophysical data, along with surficial geological maps (LGRB 2012), and a 10-m digital elevation model (LGL 2009). Figure 5a presents "along" and "cross-valley" cross-sections, exported from the geological model. Figure $5 \mathrm{~b}$ shows the profile-lines of the cross-sections together with the drilling locations used for the construction of the geological model. Both cross-sections in Fig. 5a display the extensive horizontal layering of the central floodplain lithology, with the highest variations in thickness towards the hillslopes. In the cross-valley direction, the Tufa and Gravel facies generally thicken towards the middle of the floodplain, whereas the Lower Clay becomes thinner. The Upper Clay is relatively uniform in thickness; however, a thickening trend is evident near the Ammer River, as observed from the drill cores. Moving towards the southern hillslope, the floodplain lithofacies pinch out as supported by vertical logs of natural gamma radiation marked in the cross sections (Fig. 5a). The across-valley cross-section is in line with a small tributary valley. Here, the lithofacies of the tributary-valley filling, denoted "Hillslope Aquifer" in the legend of Fig. 5, fingers into the floodplain and seems to be in contact with all floodplain facies.

\section{Hydrogeology}

\section{Floodplain and hillslope hydrostratigraphy}

Based on the lithological (primary and secondary textures) and geometric parameters (extent and continuity), the geological features were grouped into hydrostratigraphic units. The uppermost fine-textured alluvial deposit is considered a regional aquitard (Upper Clay Aquitard; Fig. 5c). Due to capillary forces, the lower half of the alluvium remains watersaturated for most of the year, whereas the top meter shows shrinkage cracks in dry summer/fall periods. The latter may facilitate temporary preferential flow paths during summer storm events.

The underlying tufa sediments are highly heterogeneous and permanently water-saturated. As the horizontal continuity of individual layers is uncertain, the entire Tufa sequence was interpreted as a single regional aquifer ("Tufa Aquifer"; Fig. $5 \mathrm{c})$. Monitoring wells were installed to target the coarsegrained sections in the upper 2-3 $\mathrm{m}$ of the Tufa Aquifer. Well tests revealed estimates of aquifer transmissivity covering four orders of magnitude; however, the majority fell within the range of $10^{-4}$ to $10^{-6} \mathrm{~m}^{2} / \mathrm{s}$, with a geometric mean on the order of $1.8 \times 10^{-5} \mathrm{~m}^{2} / \mathrm{s}$ (Fig. $5 \mathrm{c}$ ).

The Tufa Aquifer is continuously underlain by the Lower Clay, which is interpreted as a regional aquitard (Lower Clay 


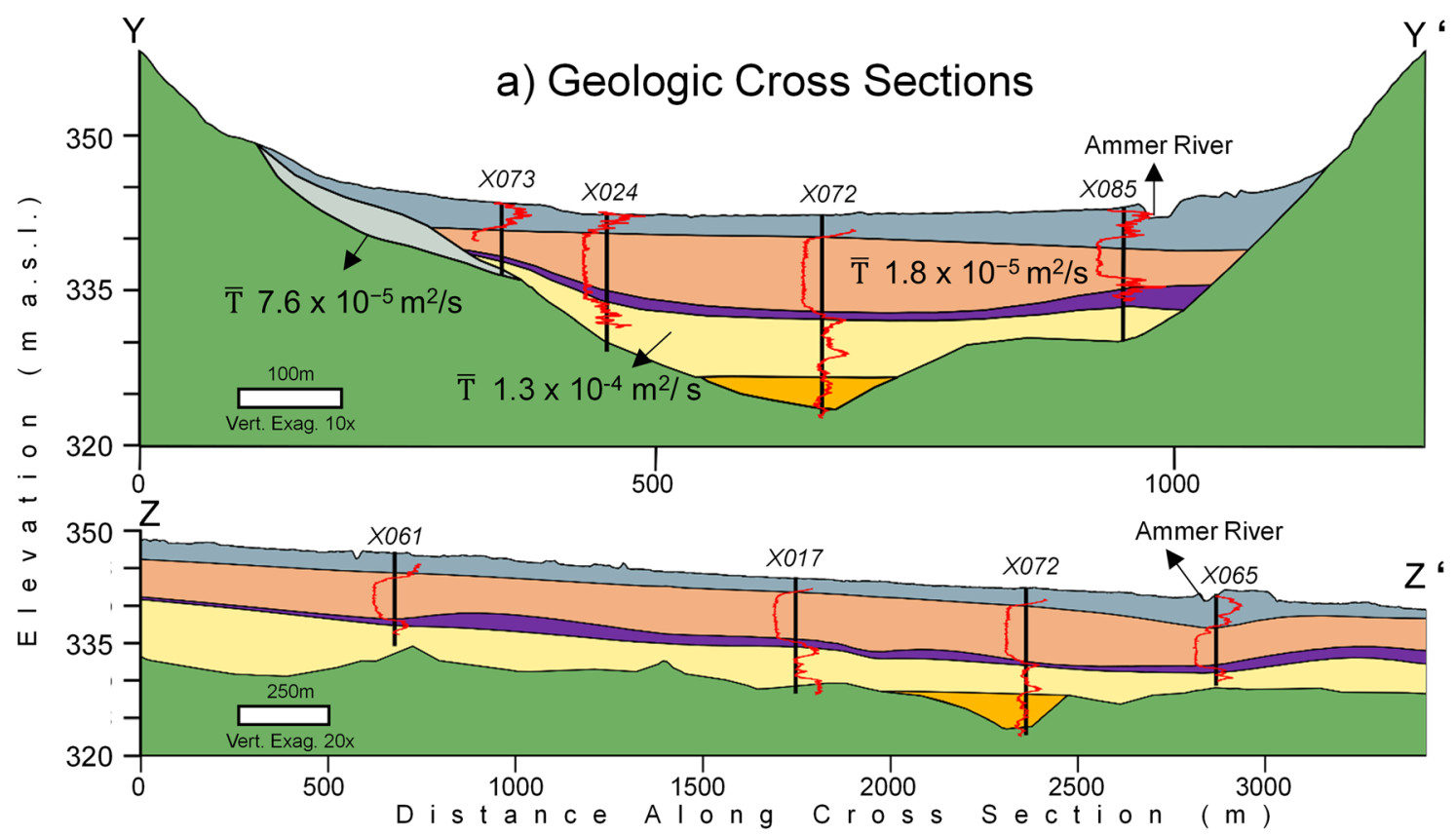

b) Overview Map

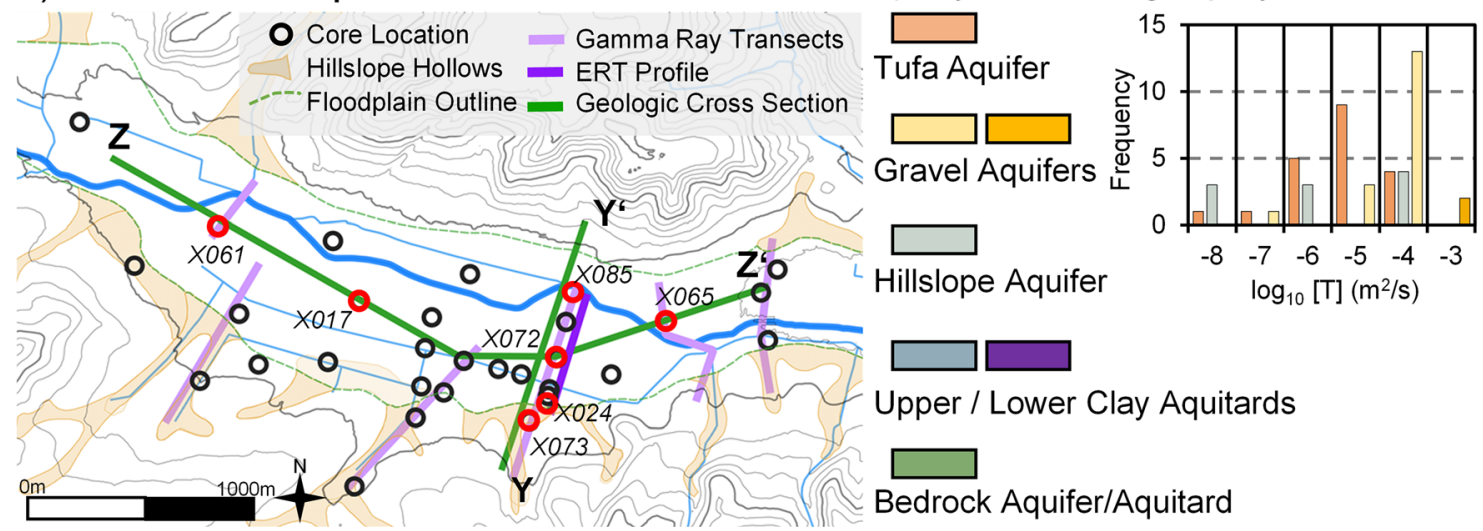

Fig. 5 Floodplain and Hillslope Stratigraphy. a Along-valley geological profile $\left(\mathrm{Y}-\mathrm{Y}^{\prime}\right)$ and cross-valley geologic profile $\left(\mathrm{Z}-\mathrm{Z}^{\prime}\right)$; b overview map of core locations, where red circles indicate the core locations included in

aquitard; Fig. 5c). It separates the tufa sediments from the lowermost Gravel lithofacies, which extends across the majority of the floodplain and is interpreted as a regional aquifer ("Gravel Aquifer"; Fig. 5c). A second set of monitoring wells targeting the Gravel Aquifer was installed over its full thickness. Though Gravel Aquifer transmissivity estimates from well tests span three orders of magnitude, the vast majority are near $10^{-4} \mathrm{~m}^{2} / \mathrm{s}$, resulting in a geometric mean on the order of $1.3 \times 10^{-4} \mathrm{~m}^{2} / \mathrm{s}$ (Fig. $5 \mathrm{c}$ ). These values are quite small for a gravel body but consistent with the high clay content. In the clean gravel channel at depth (marked in dark yellow in Fig. 5 ), determined by geoelectrical monitoring, the aquifer transmissivity was substantially higher, $\approx 1.2 \times 10^{-3} \mathrm{~m}^{2} / \mathrm{s}$.

The hillslope lithofacies within the southern tributary valleys are extremely heterogeneous, containing clayey material to gravel-sized clasts. Coarser material, found at the basal the geological profiles; c geologic features grouped into hydrostratigraphy along with aquifer transmissivity estimates from single-well recovery tests

interface with the bedrock, are water-saturated and considered as an aquifer (Hillslope Aquifer; Fig. 5c). Monitoring wells targeting shallow and deep hillslope water-bearing sediments were installed and well tests were performed, yielding highly variable estimates of aquifer transmissivity ranging from $1 \times$ $10^{-7}$ to $2.5 \times 10^{-4} \mathrm{~m}^{2} / \mathrm{s}$ (Fig. $5 \mathrm{c}$ ).

\section{Hydraulic heads in the floodplain and Hillslope Aquifers}

Figure 6 presents the groundwater contour maps from July 2019 for the Tufa and Gravel aquifers, constructed from observations in 31 and 21 monitoring wells, respectively. The dashed contour lines refer to estimated groundwater levels in the hillslopes, which were constructed by including the hillslope monitoring wells in the kriging estimate of groundwater levels. 
Groundwater flow in the Tufa Aquifer is mainly oriented along the valley (along-valley, Fig. 6a). Close to the southern boundary and within the hillslopes, a significant cross-valley component exists, suggesting that shallow groundwater from the southern hillslope enters the Tufa Aquifer, is translated towards the center of the floodplain, and then subsequently transferred down-valley. At the northern boundary, a strong curvature in the groundwater elevation contours is most evident in the eastern portion of the Tufa Aquifer near the Himbach Valley (eastern end in Fig. 6a), indicating an influx of groundwater from this tributary valley. Groundwater flow within the Gravel Aquifer is predominantly along-valley (Fig. $6 b$ ), while similar to the Tufa Aquifer, there is some crossvalley groundwater flow in the eastern portion of the aquifer, whereas the influence of the southern boundary appears to be smaller in the Gravel Aquifer than in the Tufa Aquifer.

As shown in Fig. 2, the southern hillslope extends all along the Wurmlingen Saddle and is mainly covered by agricultural land. Water infiltrating along this hillslope most likely contains solutes of agricultural origin that may enter the floodplain groundwater, having a bigger impact on flow in the Tufa than in the Gravel Aquifer, as indicated by the groundwater contour maps.

The origin of the substantial groundwater discharge, entering the study area at its western upstream end into both floodplain aquifers, is beyond the scope of the current study. This water may have been recharged by the Ammer River at the location where the floodplain valley widens, it may be
Fig. 6 Water-table elevation contour maps. a Tufa and $\mathbf{b}$ Gravel Aquifer. Contour spacing is $0.5 \mathrm{~m}$, where dashed lines indicate that the hydraulic head contours are beyond the aquifer extent a) Tufa Aquifer

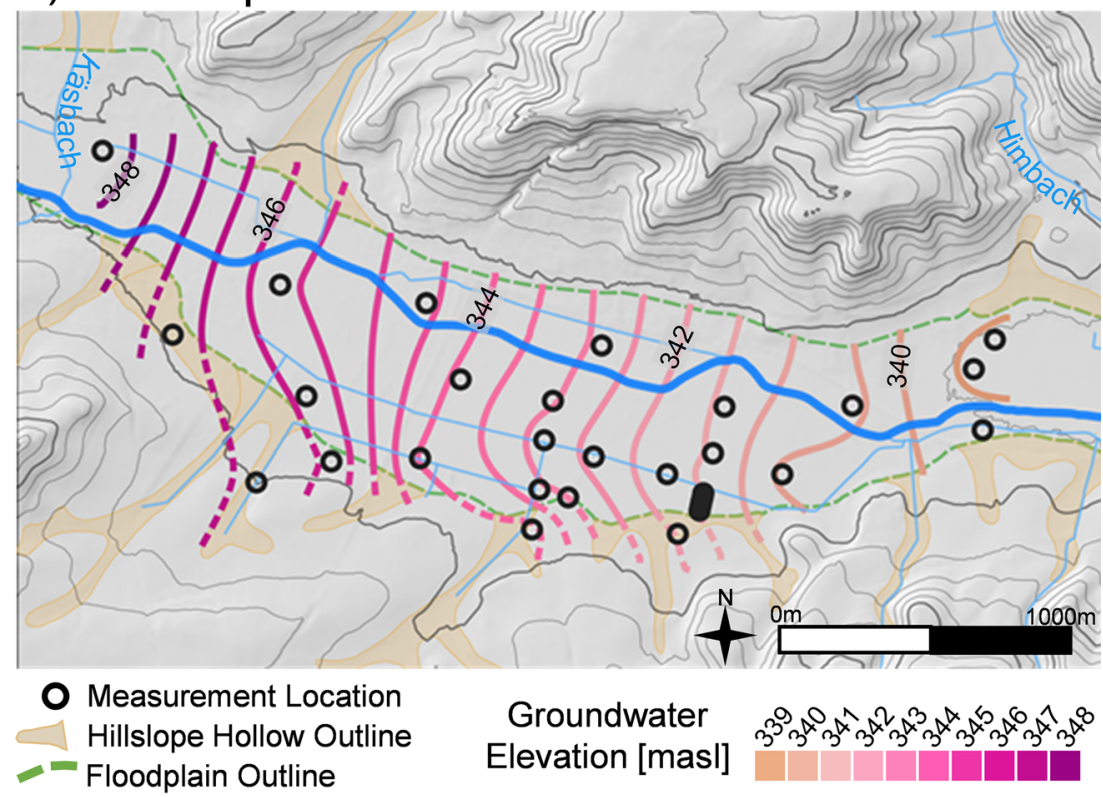

\section{b) Gravel Aquifer}

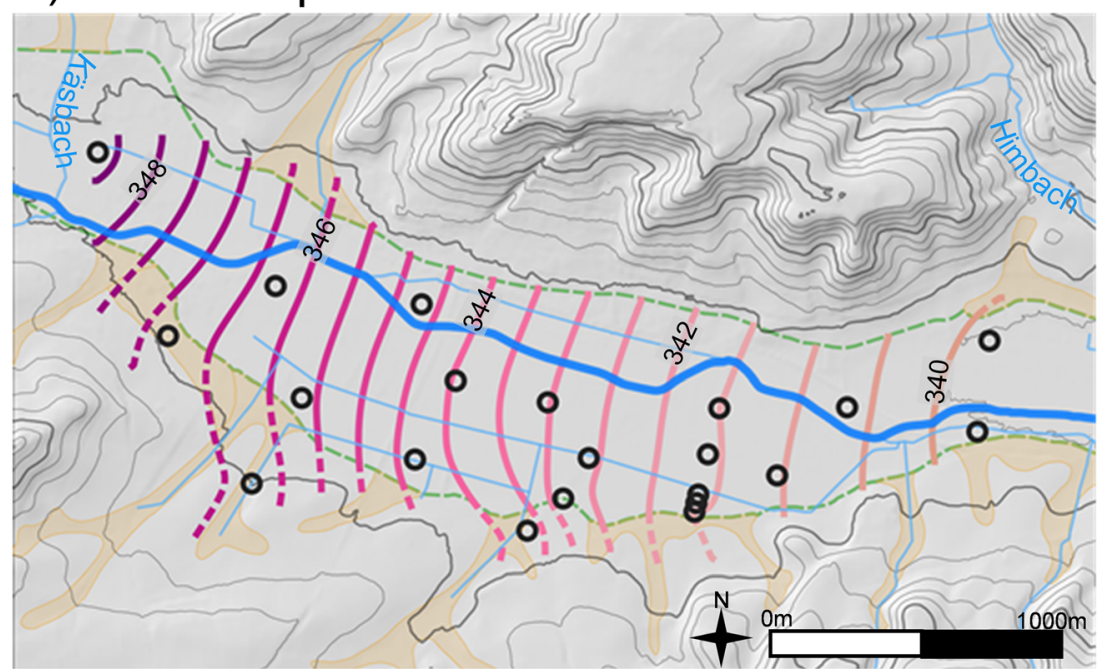


contributed by inflows from the karstic Muschelkalk aquifer at the fault line west of the study area, or it may originate from the northern tributary valley of the Käsbach stream. Local groundwater recharge in the floodplain itself is limited by the extended coverage by alluvial fines in the entire floodplain.

\section{Groundwater dynamics}

Figure 7 compares weekly averaged data of groundwater level, precipitation, and river stage to reveal the spatiotemporal dynamics of the floodplain and hillslope groundwater systems. Until June 2019, the seasonal dynamics in both groundwater systems are characterized by four main time periods, denoted a-d in Fig. 7, whereby periods a and $\mathrm{c}$ are characterized by declining groundwater levels, while periods $\mathrm{b}$ and $\mathrm{d}$ show rising groundwater levels. The periods reflect seasonal fluctuations in precipitation and evapotranspiration, causing little groundwater recharge from late spring until fall, and enhanced groundwater recharge in the winter months. Note that the winter 2017/2018 was exceptionally wet and the year 2018 extremely dry from late spring until fall. As a consequence, the high-water-table period b ended in March 2018, whereas the similar period d extended until the end of the period discussed here (June 2019), which was caused by strong precipitation events in the late spring of 2019. Figure 7a illustrates that the shallow and deep monitoring wells in the hillslope (X016) and floodplain (X019, X015 and X012) aquifers differ in their temporal dynamics, with the shallow wells responding more quickly to precipitation events in the wet periods $b$ and $d$. Among all monitoring wells, the shallow hillslope wells showed the strongest response to precipitation events in times of high water tables.

Vertical hydraulic gradients between the Tufa and Gravel aquifers vary both in space and over the seasons. In the upvalley floodplain (X019) and the hillslope (X016) locations, the vertical hydraulic-head differences are generally small, except in response to precipitation events in the high-level periods $b$ and $d$, when water tables in the shallow observation wells are higher than in the deep wells. In the two down-valley floodplain locations (X015 and X012), the hydraulic heads are significantly higher in the deep wells compared to the shallow ones in the periods a and c of declining groundwater levels, whereas the differences are much smaller during the wet periods $\mathrm{b}$ and $\mathrm{d}$.

Altogether, Fig. 7 shows that groundwater levels in the hillslope and the floodplain exhibit essentially the same seasonal trends, whereas fluctuations of the river hydrograph and the groundwater levels hardly correlate. The hillslope groundwater levels show the strongest and fastest response to individual rainfall events, followed by the Tufa Aquifer, and finally the Gravel Aquifer, for which responsiveness strongly depends on the season.

\section{Hydrogeochemistry}

The initial regional field study included at least fivefold sampling of each monitoring well, resulting in robust hydrochemical datasets for all aquifers. Table 1 summarizes the average physical and hydrochemical parameters of the Tufa, Gravel, and southern Hillslope aquifers. The ion balances of all aquifers are dominated by the cations calcium and magnesium and by the anions bicarbonate and sulfate,
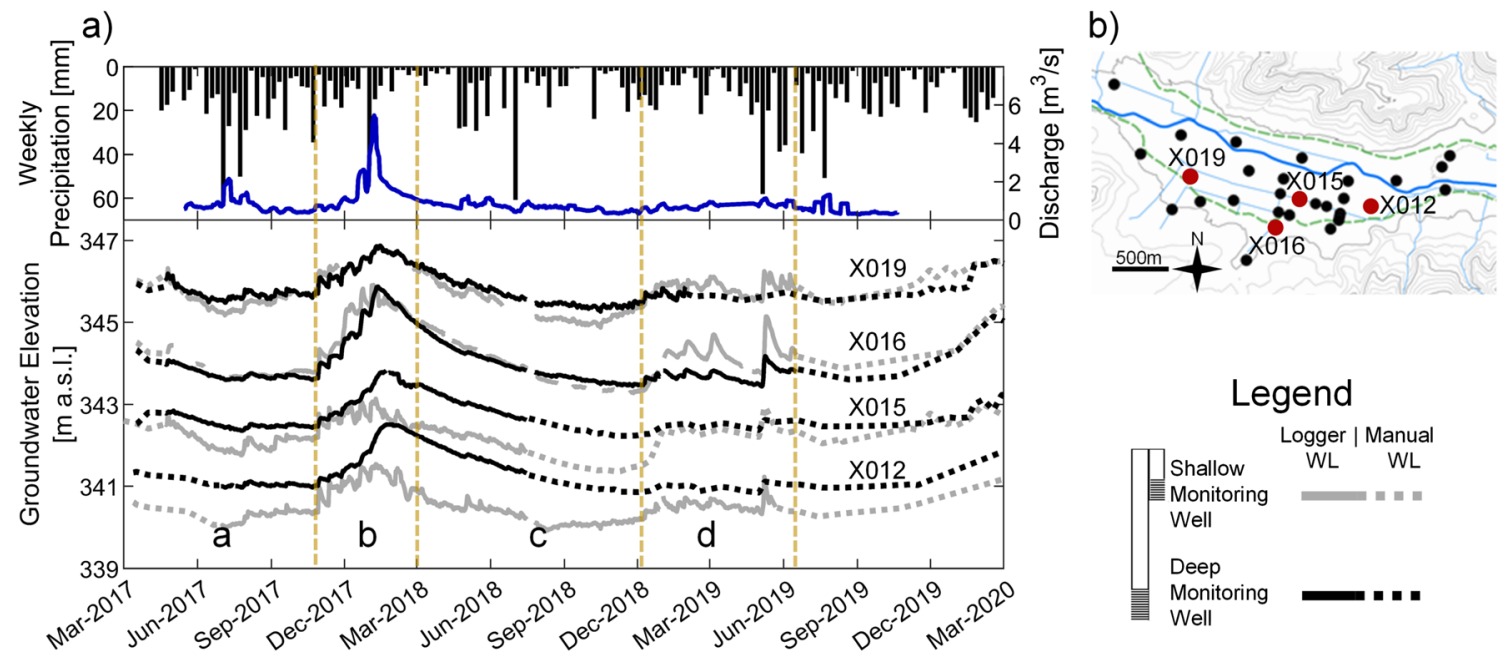

Fig. 7 Groundwater Dynamics. a Weekly floodplain groundwater elevation time-series data for selected nested monitoring wells (gray: shallow; black: deep monitoring well) from upstream towards downstream within the section of the floodplain, along with weekly

precipitation and river discharge. The time-series until June 2019 can be separated into four hydrological time periods (a-d). b Location of monitoring wells (also shown on the overview map in Fig. 5) 
accounting for more than $95 \%$ of total dissolved ions. The average hydrochemical compositions of groundwater in the two floodplain aquifers are quite similar, with the main differences that sulfate and nitrate concentrations are higher in the Gravel Aquifer, and that the Tufa Aquifer shows lower fieldmeasured redox potential and higher dissolved organic carbon values. The southern Hillslope Aquifer has an approximately $33 \%$ lower ion content in the groundwater than the floodplain aquifers, with calcium /magnesium ratios similar to the floodplain aquifers, but significantly higher bicarbonate/sulfate ratios, due to the lower sulfate concentrations. It was observed that there was very little seasonal variability in the hydrochemistry of the regional aquifers (data not shown), but event-based sampling of the entire monitoring-well network was not performed so it was not possible to report on the hydrochemical signatures of individual precipitation events.

The subsequent sections discuss in more detail the results of a comprehensive sampling campaign in July 2019, in which all monitoring wells, the Ammer River, a tributary stream within the floodplain (Mühlbach), two springs at the toe of the southern hillslope (see Fig. 2) and one spring at the northern hillslope in the Käsbach tributary, $3 \mathrm{~km}$ from the Ammer floodplain, were sampled. In the maps of Figs. 8 and 9, hydrochemical data of shallow hillslope monitoring wells are shown together with data of the Tufa Aquifer, whereas those of deep hillslope monitoring wells are merged with Gravel Aquifer data. Hillslope samples of locations with a single depth are accounted for in the maps of both aquifers.

\section{Provenance of floodplain and hillslope groundwater}

Figure 8a shows scatter plots of sulfate, bicarbonate, magnesium, calcium concentrations, and groundwater electrical conductivity (EC). Figure $8 \mathrm{~b}$ contains a hydrochemical cluster analysis of all samples, whereas Fig. 8c,d present maps of EC in the two floodplain aquifers.

Floodplain and hillslope groundwater samples of the July 2019 campaign showed positive correlations between EC and calcium, magnesium and sulfate concentrations, whereas no clear relationship between EC and bicarbonate
Table 1 Regional groundwater chemistry. Summary of physical and chemical floodplain and hillslope water quality parameters. Data presented are mean values (along with standard deviation) from all groundwater sampling campaigns conducted between 2017 and 2020

\begin{tabular}{|c|c|c|c|c|c|c|}
\hline \multicolumn{3}{|l|}{ Parameters } & \multirow{2}{*}{$\begin{array}{l}\text { Units } \\
{[-]}\end{array}$} & \multirow{2}{*}{$\begin{array}{l}\begin{array}{l}\text { Tufa } \\
\mu \pm \sigma\end{array} \\
7.00 \pm 0.18\end{array}$} & \multirow{2}{*}{$\begin{array}{l}\text { Gravel } \\
\mu \pm \sigma\end{array}$} & \multirow{2}{*}{$\begin{array}{l}\text { Hillslope } \\
\mu \pm \sigma\end{array}$} \\
\hline Physical & & $\mathrm{pH}$ & & & & \\
\hline & & Temp. & {$\left[{ }^{\circ} \mathrm{C}\right]$} & $12.2 \pm 2.60$ & $12.0 \pm 1.50$ & $12.4 \pm 2.50$ \\
\hline & & $\mathrm{EC}$ & {$[\mu \mathrm{S} / \mathrm{cm}]$} & $1210 \pm 570$ & $1290 \pm 530$ & $870 \pm 120$ \\
\hline & & DO & {$[\mathrm{mg} / \mathrm{L}]$} & $0.58 \pm 1.09$ & $0.55 \pm 0.98$ & $2.86 \pm 2.27$ \\
\hline & & Eh & {$[\mathrm{mV}]$} & $14.1 \pm 53.3$ & $72.3 \pm 92.7$ & $197 \pm 66.7$ \\
\hline \multirow[t]{21}{*}{ Chemical } & \multirow[t]{10}{*}{ Cations } & $\mathrm{Ca}^{2+}$ & {$[\mathrm{mg} / \mathrm{L}]$} & $203 \pm 125$ & $214 \pm 123$ & $130 \pm 38.4$ \\
\hline & & & {$[\mathrm{meq} / \mathrm{L}]$} & $10.1 \pm 6.2$ & $10.7 \pm 6.1$ & $6.48 \pm 1.92$ \\
\hline & & $\mathrm{Mg}^{2+}$ & {$[\mathrm{mg} / \mathrm{L}]$} & $49.9 \pm 18.2$ & $59.9 \pm 16.0$ & $45.0 \pm 7.76$ \\
\hline & & & {$[\mathrm{meq} / \mathrm{L}]$} & $4.10 \pm 1.50$ & $4.93 \pm 1.32$ & $3.70 \pm 0.64$ \\
\hline & & $\mathrm{Na}^{+}$ & {$[\mathrm{mg} / \mathrm{L}]$} & $8.29 \pm 5.08$ & $6.14 \pm 4.21$ & $6.46 \pm 2.22$ \\
\hline & & & {$[\mathrm{meq} / \mathrm{L}]$} & $0.36 \pm 0.22$ & $0.27 \pm 0.18$ & $0.28 \pm 0.10$ \\
\hline & & $\mathrm{NH}_{4}^{+}$ & {$[\mathrm{mg} / \mathrm{L}]$} & $4.50 \pm 4.38$ & $4.62 \pm 5.02$ & $0.50 \pm 0.98$ \\
\hline & & & {$[\mathrm{meq} / \mathrm{L}]$} & $0.25 \pm 0.24$ & $0.26 \pm 0.28$ & $0.028 \pm 0.054$ \\
\hline & & $\mathrm{K}^{+}$ & {$[\mathrm{mg} / \mathrm{L}]$} & $2.43 \pm 3.73$ & $3.21 \pm 3.88$ & $1.64 \pm 1.18$ \\
\hline & & & {$[\mathrm{meq} / \mathrm{L}]$} & $0.062 \pm 0.095$ & $0.082 \pm 0.099$ & $0.042 \pm 0.03$ \\
\hline & \multirow[t]{11}{*}{ Anions } & $\mathrm{HCO}_{3}^{-}$ & {$[\mathrm{mg} / \mathrm{L}]$} & $636 \pm 121$ & $571 \pm 135$ & $554 \pm 97.9$ \\
\hline & & & {$[\mathrm{meq} / \mathrm{L}]$} & $10.4 \pm 2.00$ & $9.35 \pm 2.20$ & $9.08 \pm 1.60$ \\
\hline & & $\mathrm{SO}_{4}{ }^{2-}$ & {$[\mathrm{mg} / \mathrm{L}]$} & $232 \pm 408$ & $347 \pm 422$ & $57.3 \pm 62.4$ \\
\hline & & & {$[\mathrm{meq} / \mathrm{L}]$} & $4.83 \pm 8.50$ & $7.21 \pm 8.79$ & $1.19 \pm 1.30$ \\
\hline & & $\mathrm{Cl}^{-}$ & {$[\mathrm{mg} / \mathrm{L}]$} & $15.0 \pm 17.5$ & $16.5 \pm 17.6$ & $10.4 \pm 5.9$ \\
\hline & & & {$[\mathrm{meq} / \mathrm{L}]$} & $0.42 \pm 0.49$ & $0.46 \pm 0.50$ & $0.29 \pm 0.17$ \\
\hline & & $\mathrm{NO}_{3}^{-}$ & {$[\mathrm{mg} / \mathrm{L}]$} & $1.81 \pm 6.31$ & $5.33 \pm 10.9$ & $12.1 \pm 11.1$ \\
\hline & & & {$[\mathrm{meq} / \mathrm{L}]$} & $0.029 \pm 0.102$ & $0.086 \pm 0.176$ & $0.19 \pm 0.18$ \\
\hline & & $\mathrm{F}^{-}$ & {$[\mathrm{mg} / \mathrm{L}]$} & $0.27 \pm 0.07$ & $0.31 \pm 0.09$ & $0.30 \pm 0.10$ \\
\hline & & & {$[\mathrm{meq} / \mathrm{L}]$} & $0.014 \pm 0.004$ & $0.016 \pm 0.005$ & $0.016 \pm 0.005$ \\
\hline & & DOC & {$[\mathrm{mg} / \mathrm{L}]$} & $5.41 \pm 3.12$ & $2.95 \pm 2.00$ & $2.73 \pm 2.06$ \\
\hline
\end{tabular}




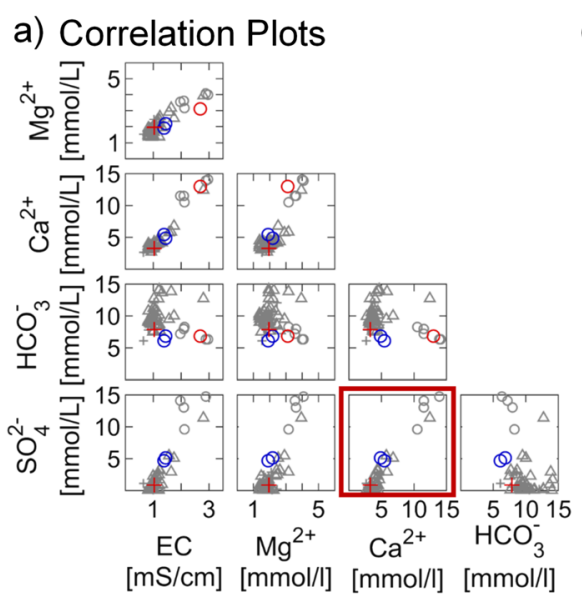

\section{c) Tufa Aquifer}

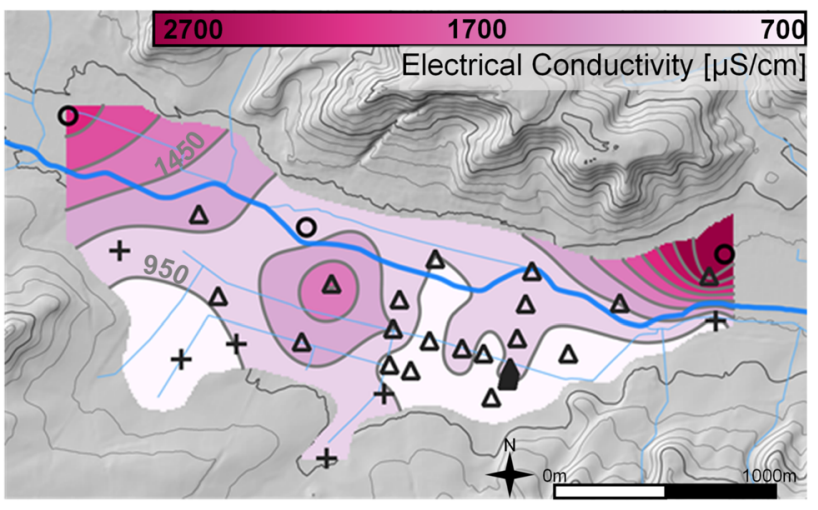

$[\mathrm{mS} / \mathrm{cm}][\mathrm{mmol} / \mathrm{l}][\mathrm{mmol} / \mathrm{l}][\mathrm{mmol} / \mathrm{l}]$

\begin{tabular}{|c|c|c|c|c|}
\hline Legend & $\begin{array}{c}\mathrm{O}+\text { North/South Spring } \\
\text { Stream Water }\end{array}$ & O I & + II & $\triangle \mathrm{III}$ \\
\hline
\end{tabular}

b) Hierarchical Cluster Analysis

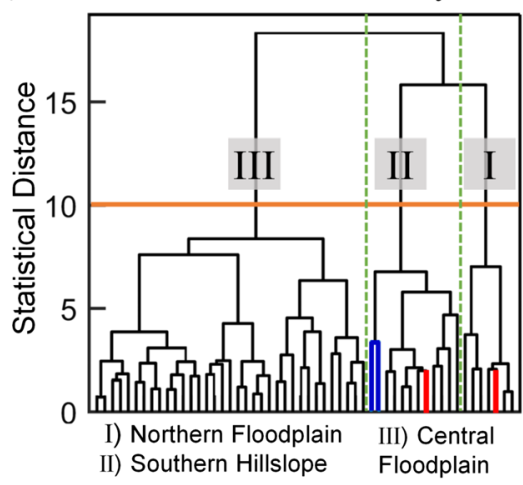

d) Gravel Aquifer

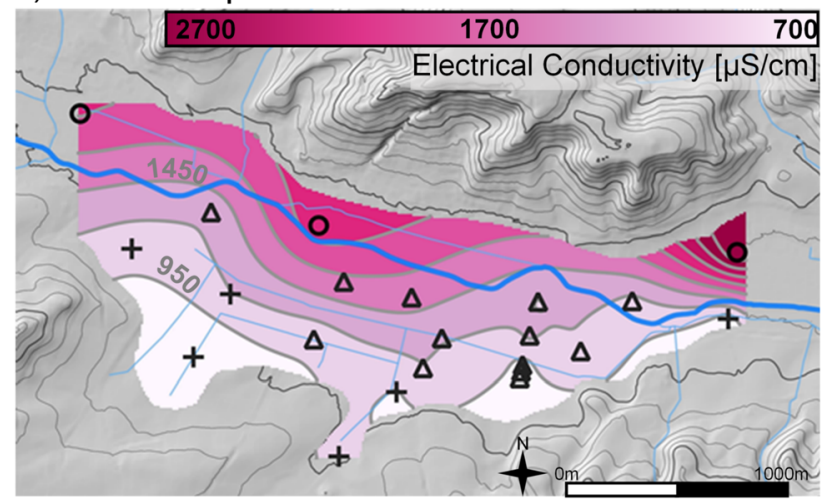

Fig. 8 Provenance of floodplain and hillslope groundwater. a Pairwise scatter plots of major ions and electrical conductivity (EC) for all groundwater samples (black symbols), grab samples of surface water bodies (blue circles), and north (red circle) and south (red cross) springs. b Hierarchical cluster analysis of floodplain and hillslope groundwater

concentrations can be observed (Fig. 8a). EC clusters at approximately $1,200 \mu \mathrm{S} / \mathrm{cm}$, and some samples reach up to $3,000 \mu \mathrm{S} / \mathrm{cm}$. A near 1:1 relationship between sulfate and calcium, especially in samples with EC> $1,200 \mu \mathrm{S} / \mathrm{cm}$, indicates gypsum dissolution (red box, Fig. $8 \mathrm{a}$ ), which can be explained by the gypsum-bearing mudstones of the Grabfeld formation.

Figure $8 \mathrm{~b}$ presents results of a hierarchical cluster analysis based on an extended hydrochemical dataset, including more hydrochemical parameters than shown in the scatter plots of Fig. 8a. All parameters were z-score normalized prior to the cluster analysis. Three clusters at a statistical distance of 10 were identified (orange line in Fig. 8b). In the maps of Fig. $8 \mathrm{c}, \mathrm{d}$, the sampling locations belonging to different clusters are visualized by different marker symbols.

Cluster I comprises highly mineralized (predominantly calcium and sulfate) groundwater samples (black circles, Fig. 8a) and the sample from the northern spring fed by the Grabfeld formation (red circle in Fig. 8a and red bar in Fig. 8b). This cluster includes samples of both the Tufa and Gravel aquifers in samples, grab samples of surface-water bodies (cluster II, blue bars), north (cluster III, red bar) and south (cluster II, red bar) springs. c and d Spatial interpolation of field-measured groundwater electrical conductivity for July 2019 in the Tufa and Gravel aquifers, respectively

northern portions of the floodplain, specifically at the confluencing tributary valleys, where EC is particularly high (Fig. 8c,d). These samples are strongly influenced by gypsum dissolution.

Cluster II consists of low mineralized groundwater samples (black crosses, Fig. 8a) and a sample of the spring at the southern hillslope (red cross in Fig. 8a and red bar in Fig. $8 \mathrm{~b})$. These samples originate from the southern Hillslope Aquifers or from southern-most monitoring wells in the floodplain aquifers, confirming the interpretation of the groundwater contour maps (Fig. 6) that the floodplain aquifers receive water from the southern hillslopes. Due to the correlation in oxidized compounds, this cluster also contains surface water samples collected from the Ammer River and the Mühlbach stream (blue circles in Fig. 8a and blue bars in Fig. 8b); however, these surface-water samples are far more similar to the central floodplain in major ion chemistry (Fig. 8a). Cluster III (Fig. 8b) contains the largest number of samples, mainly from the central floodplain (black triangles, Fig. 8a), and includes samples of both the Tufa and Gravel aquifers (Fig. 8c,d). 
Fig. 9 Redox geochemistry of floodplain groundwater. Pairwise scatter plots of redox-relevant groundwater species (left) and spatial interpolation of fieldmeasured redox potential for July 2019 (right) for the a Tufa and $\mathbf{b}$ Gravel aquifers a)
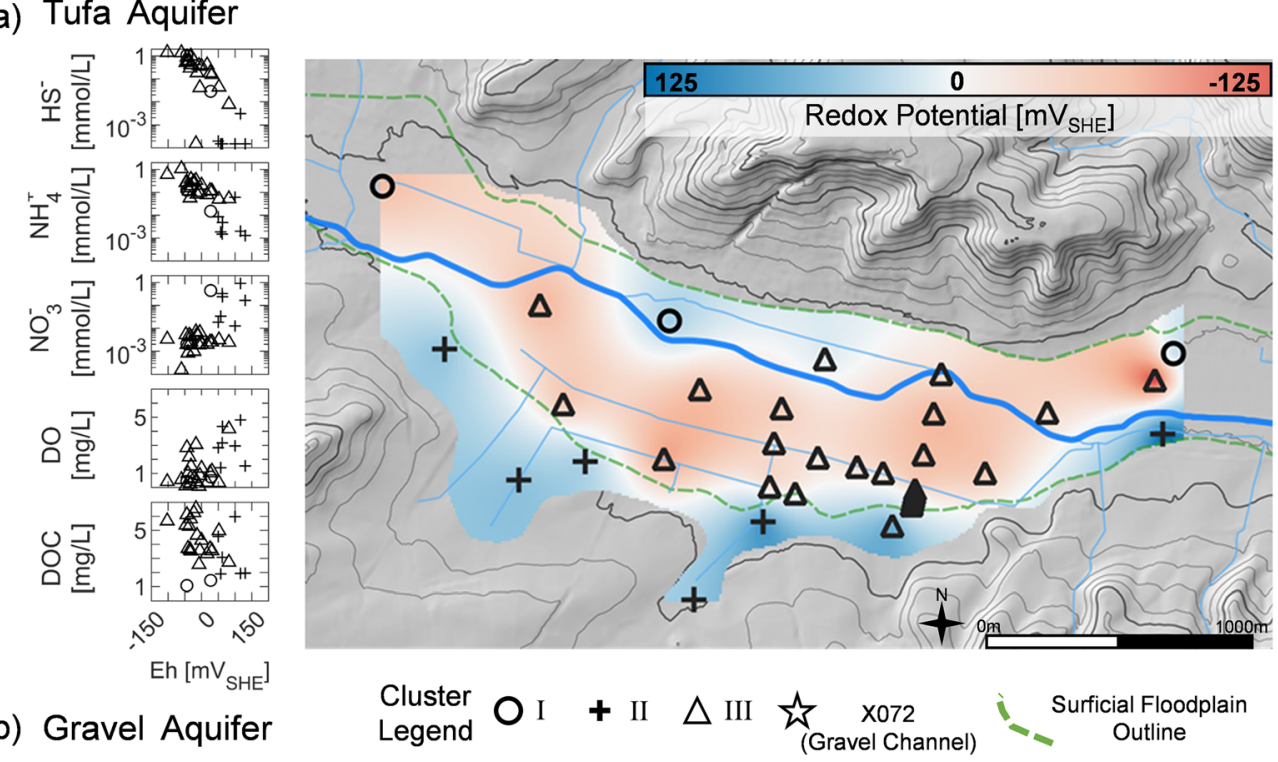

b) Gravel Aquifer
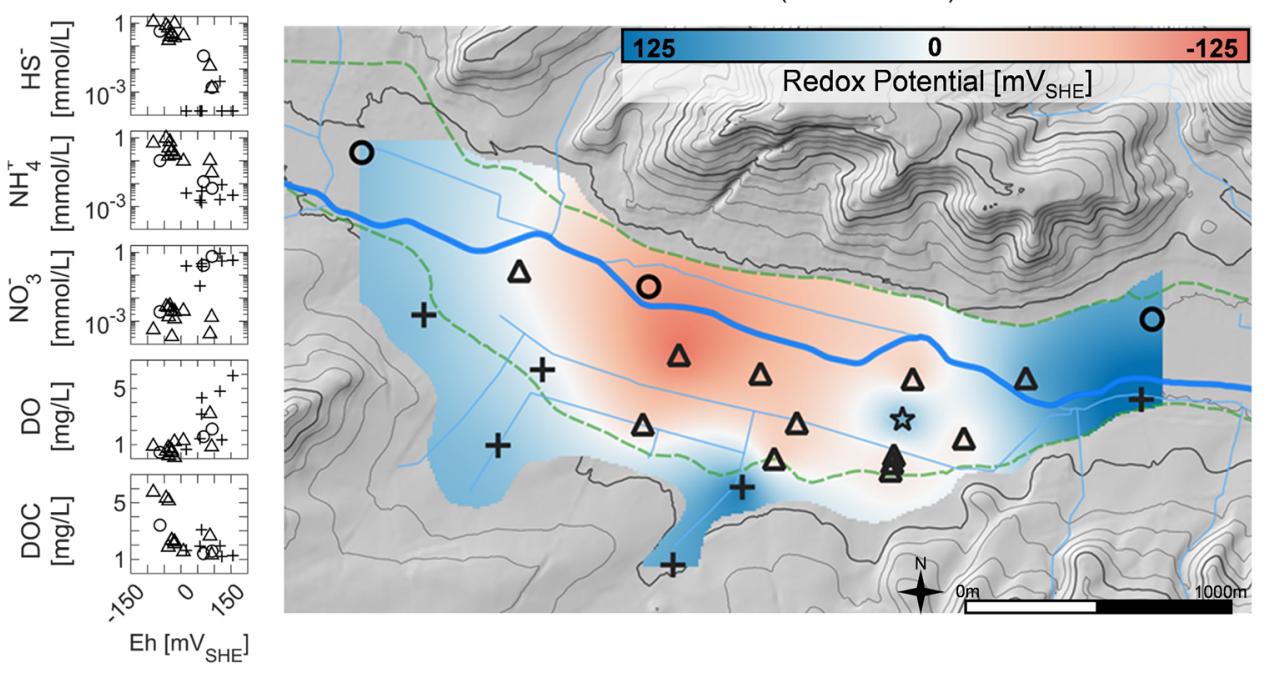

\section{Redox geochemistry of floodplain groundwater}

Figure 9 shows scatterplots of redox-indicating concentrations versus field-measured redox potentials (Eh) of the sampling campaign in July 2019 as well as maps of interpolated Eh values in the Tufa and Gravel aquifers. Like in Fig. 8, the Eh-map of the Tufa Aquifer in Fig. 9a includes measurements of shallow observation wells in the Hillslope Aquifer, and the Eh-map of the Gravel Aquifer in Fig. 9b includes those of deep observation wells in the Hillslope Aquifer. The marker symbols in the scatter plots and the maps refer to the hydrochemical cluster affiliations of the samples discussed previously.

The scatterplots of Fig. 9a,b confirm that fieldmeasurements of Eh yield a good qualitative assessment of redox-sensitive species, in which high Eh values indicate low concentrations of the reduced species bisulfide and ammonium and high concentrations of electron acceptors nitrate and dissolved oxygen. Dissolved organic carbon (DOC) showed a much weaker relationship with Eh. In many scatter plots, the previously described clustering is quite evident, especially with groundwater samples from the southern portion of the floodplain and the Hillslope aquifer (black crosses, Fig. 9a,b). A quantitative analysis of defined redox pairs (bisulfide/sulfate and ammonium/nitrate) by the Nernst equation, however, yielded calculated redox potentials that were substantially lower than the field measurements so that the field-measured Eh values cannot be taken to compute the electron buffering capacity of the solutions.

In the maps of interpolated Eh values in Fig. 9, blue regions indicate positive field-measured Eh values and red regions negative ones. The Eh map of the Tufa Aquifer in Fig. 9a shows oxidizing conditions in the hillslope samples, with mean Eh, DO and nitrate concentration of $83 \mathrm{mV}, 3.2 \mathrm{mg} / \mathrm{L}$, and $13 \mathrm{mg} / \mathrm{L}$, respectively. The width of a transition zone with field-measured Eh values around zero, marked white in the 
map, is small $(\approx 100 \mathrm{~m})$ and uncertain because the underlying interpolation by kriging is smooth and the network of monitoring wells was not optimized to resolve the redox transition zone. Practically the entire Tufa Aquifer shows strongly reducing conditions. In the center were observed field-measured Eh-values as low as $-102 \mathrm{mV}$, and ammonium and bisulfide concentrations as high as 19 and $47 \mathrm{mg} / \mathrm{L}$, respectively. This is consistent with the Tufa containing large amounts of labile organic carbon acting as strong electron donor in the matrix. Two samples north of the Ammer River, and one south (eastern edge) show less reducing conditions, which may indicate an influence of the river.

Figure 9b shows the interpolated Eh map of the Gravel Aquifer, which differs from that of the Tufa Aquifer. Groundwater in the middle section of the Gravel Aquifer is again strongly reduced (average bisulfide concentrations: $15 \mathrm{mg} / \mathrm{L}$, field-measured Eh as low as $-83 \mathrm{mV}$ ). Hillslope samples are again oxidized, but also the sample at the western inflow of the study domain and samples at the downstream eastern end. Here, the mean values of Eh, DO and nitrate concentrations were $66 \mathrm{mV}, 1.9 \mathrm{mg} / \mathrm{L}$ and $18 \mathrm{mg} / \mathrm{L}$, respectively. The sediments in the Gravel Aquifer contain less organic matter than the Tufa, explaining a longer transition zone from oxidizing to reducing conditions, even though the true transition at the western end is not well resolved. The transition from reduced to oxidized conditions in the direction of groundwater flow from the west to the east is more difficult to explain as there cannot be an internal source of dissolved oxygen. It is believed that the channel of clean gravel underneath the clayey gravel, detected by the geoelectrical mapping campaign, acts as a preferential pathway transferring more oxidized water underneath the main sediment body with little or no chemical reduction. This channel has not been met by most wells in the center of the Gravel Aquifer, except for X072 (marked with a star in Fig. 9b). Further downstream, all wells in the Gravel Aquifer are oxidized, carrying the signature of the water in the clean gravel channel. This implies that the relative contribution of the groundwater flux through the reduced parts of the Gravel Aquifer must be small. Without such a bypassing mechanism, the observed redox pattern cannot be explained.

\section{Discussion}

\section{Representativeness of the floodplain}

\section{Hydrogeomorphic setting}

The floodplain is carved into the gypsum-bearing Triassic mudstone of the Grabfeld formation. This relatively incompetent bedrock is susceptible to weathering and facilitated the development of the wide and thick floodplain sequence observed at the study site in present day. Up- and downstream of the study area, the bedrock is much more competent (Muschelkalk limestone and sandstone of the Stuttgart Formation, respectively). Correspondingly, the floodplain becomes narrower and shallower. This characteristic landscape of alternating narrow and wide floodplains, controlled by the changing lithology along a river course, is quite common in European upland catchments with clastic bedrock. At the upstream ends of the wider basins, river water tends to infiltrate, whereas groundwater discharges back to the river at the downstream ends, triggering basin-scale riparian exchange (Fig. 10a).

The southern hillslopes extend over a length of up to $\approx$ $1 \mathrm{~km}$ (Wurmlingen Saddle, Fig. 2), whereas the northern hillslopes are comparably short and steep. Along the Wurmlingen Saddle, a substantial weathering zone of up to $20 \mathrm{~m}$ thickness has been confirmed by drill cores, which is common in landscapes with hilly topography and bedrocks of low competence (Rempe and Dietrich 2014). The southern hillslopes are also characterized by pronounced hillslope hollows, which consist of thick, fine-grained, poorly sorted colluvium, produced by solifluction processes typical of the periglacial environment (Collins et al. 2006).

On the steep northern slopes, the bedrock is less weathered and correspondingly less permeable. Two large tributary valleys confluence the floodplain at the upstream and downstream end of the study area. Here the hillslope deposits are interpreted as alluvial fans and thus expected to contain coarser-grained sediments in comparison to the southern slopes. Altogether, hillslope deposits, particularly those in hillslope hollows or tributary valleys, can collect regional groundwater recharge along the hillslopes and transfer them into both floodplain aquifers as these deposits pinch out over the entire thickness of the floodplain filling.

The location of the groundwater divide on the southern hillslope is unclear and depends on the exact thickness of the weathering layer. In principle, the Neckar Valley south of the Wurmlingen Saddle is topographically lower, which may shift the groundwater divide into the Ammer Valley, provided that sufficiently permeable material reaches deep enough (Kortunov 2018). Such ambiguities are fairly typical for mudstones in hilly topographies and have a large influence on the local water balance.

\section{Floodplain depositional setting}

The fluvial systems of many European rivers have shown significant response to the environmental change from the late Pleistocene to Holocene time periods, which is captured in the fluvial sediment record (Collins et al. 2006; Lespez et al. 2008). Gibbard and Lewin (2002) present a conceptual geological model for floodplain stratigraphy common in small- to medium-sized European rivers: high-energy late Pleistocene gravels preserved at the base, followed by the deposition of 


\section{a) Hydrogeomorphic Setting}

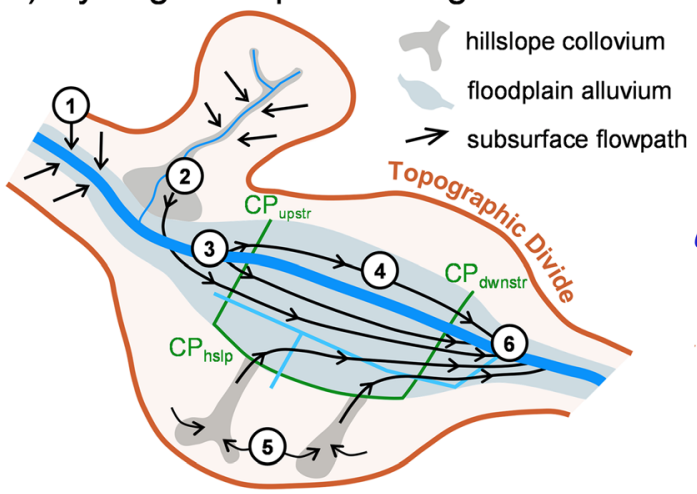

(1) upstream, hard bedrock, narrow floodplain : exfiltrating GW conditions

(2) leaky headwater subcatchment infiltrating GW conditions

(3) upstream, soft bedrock, widening floodplain: infiltrating GW conditions

(4) midstream, soft bedrock, wide floodplain: near-river along-valley GW flow

(5) midstream, soft bedrock, wide hillslope: focused GW flow in hillslope hollows

(6) downstream, hard bedrock, narrowing floodplain: exfiltrating GW conditions b) Floodplain Water Balance

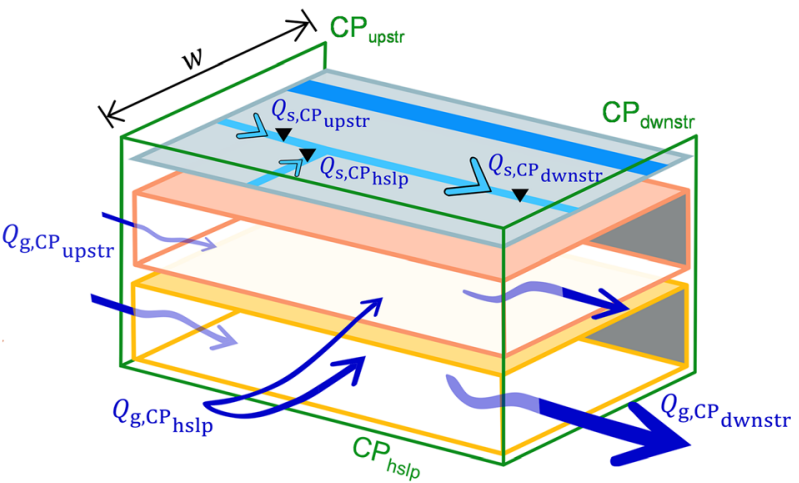

Groundwater Flux Balance Equation

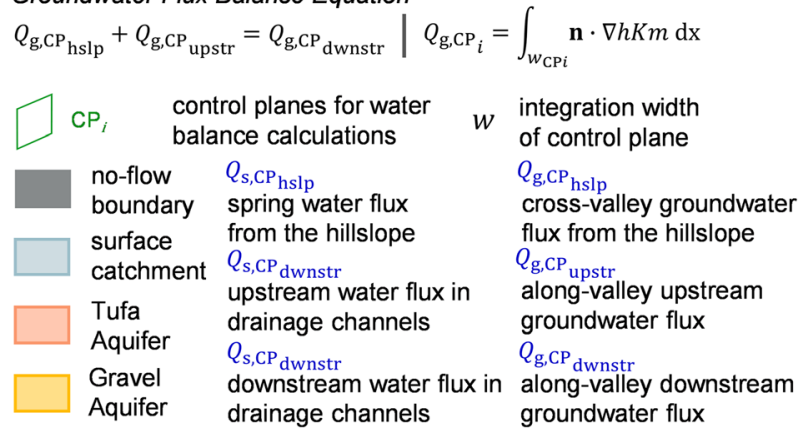

Fig. 10 Hydrogeomorphic setting and floodplain water balance. a The hydrogeomorphic setting of a typical river catchment in a temperate climate. b Illustration of the setup of the floodplain water balance. GW groundwater

fine-grained, organic-rich (and possibly tufaceous) sediments from the warmer Atlantic period in the Holocene, and finally a thick anthropogenically impacted alluvium blanketing the present-day floodplain. The subsequent interpretation, of the collected geological data, supports this representative floodplain stratigraphy (from oldest to youngest):

1. The lowermost floodplain stratigraphic unit consists of poorly sorted and nonstratified sand and gravel within a fine-grained silt and clay matrix. A multiple-source gravel composition (both from upstream and hillslope bedrock units), along with the high content of fines, suggests variable energy depositional setting: a high-energy braided river system along-valley with low-energy solifluction deposits providing abundant fine sediment from the hillslope, typical of a late Pleistocene, periglacial environment in many parts of Europe (Hagedorn and Rother 1992; Houben 2003; Collins et al. 2006; Roe and Preece 2011). The geophysical record suggests a channel of clean gravel underneath the clayey-gravel deposits, which may be crucial for the hydrogeological functioning of the floodplain (see the following).

2. The lower clay lithofacies forms a relatively thin but continuous layer throughout the study area; however, it significantly thins out towards the middle of the floodplain (Fig. 4a), suggesting that the clay layer may be locally discontinuous. The presence of well-rounded sand and gravel-sized clasts within the structureless clay (Fig. 3c) represents variable sediment flux and transport velocities, interpreted as a migrating, possibly anastomosing, lowenergy channel environment, as observed in many regions of Europe at the end of the Pleistocene (Gilvear et al. 1997; Collins et al. 2006).

3. The overlying Tufa lithofacies is thick and highly heterogeneous, forming a continuous layer across the study area, with clear thickening downstream as well as towards the middle of the floodplain, resulting in a lens-shape in cross-section (Fig. 4a). This unit comprises interbedded layers of micritic tufa, larger granular tufa, peat layers $(0.5-1 \mathrm{~m})$ with well-preserved vegetation, and abundant gastropod shells. These characteristics are typical for a low-energy anastomosing-channels environment with intense vegetation growth, fall into a paludal depositional environment model (Pedley 1990), and are very common throughout Europe (Dramis et al. 1999; Žák et al. 2002; Collins et al. 2006; Lespez et al. 2008; Pazzaglia et al. 2013; Dabkowski 2020).

4. Blanketing the entire floodplain, the thick uppermost clay lithofacies comprises both the modern floodplain alluvium and the soil zone, developed from a long history of widespread agricultural activity. This agricultural activity is facilitated by an extensive network of drainage channels, which transitioned the persistent wetland to the present-day drained floodplain. These recent alluvial 
deposits are common throughout Europe and are both naturally derived (overbank flood events) as well as anthropogenically impacted (Collins et al. 2006; Brown et al. 2013, 2018).

While the general depositional sequence of the Ammer floodplain is fairly common, its local specification determines the hydrogeological functioning of the floodplain (right side, Fig. 1). This particularly refers to the extent and connectivity of highly permeable clean gravels (flowpath D, Fig. 1), their connection to hillslope deposits (flowpath A, Fig. 1), and the intactness of the alluvial fines in the vicinity of the river (flowpath B and C, Fig. 1). If the coarser-grained deposits of the active river do not cut through the alluvial fines, the river remains decoupled from the groundwater. Also, clean-gravel deposits act as the "drainage pipe" of the floodplain, making a substantial fraction of the water flux bypass the reducing floodplain sediments.

\section{Water balance of the floodplain}

\section{Seasonal groundwater fluxes}

As illustrated in Fig. 10b, water balances for the two floodplain aquifers under steady-state conditions were set up, resulting in the following balance equation:

$Q_{\mathrm{g}, \mathrm{CP}}{ }_{\mathrm{hslp}}+Q_{\mathrm{g}, \mathrm{CP}} \mathrm{upstr}_{\mathrm{g}, \mathrm{CP}}=Q_{\mathrm{dwnstr}}$

in which $Q_{\mathrm{g}, \mathrm{CPhslp}}$ is the groundwater flux entering at the control plane at the southern hillslope-floodplain boundary, $Q_{\mathrm{g}, \text { CPupstr }}$ is the groundwater flux entering at the western boundary of the study domain, and $Q_{\mathrm{g}, \mathrm{CPdwnstr}}$ is the groundwater flux leaving at the eastern boundary of the study domain. The location of the upstream and downstream boundaries makes the groundwater inflows from the northern tributary subcatchments (Käsbach and Himbach, see Fig. 2) irrelevant to the presented floodplain water balance. Furthermore, this study did not consider any groundwater recharge within the floodplain itself because the alluvial fines are hardly permeable.

The groundwater fluxes across control planes, $Q_{\mathrm{g}, \mathrm{CP} i}$, are evaluated by integrating the specific discharge normal to the plane over the surface area of the plane:

$Q_{\mathrm{g}, \mathrm{CP} i}=\int_{w_{\mathrm{CP} i}} \mathbf{n} \cdot \nabla h K m \mathrm{~d} x$

in which $w_{\mathrm{CP} i}$ is the width of control plane $i, \mathbf{n}$ is the unit normal vector, $\nabla h$ is the hydraulic gradient estimated from the kriging interpolation, $K$ is the hydraulic conductivity derived from single-well pumping tests, and $m$ is the thickness of the aquifer derived from the geological model.
Table 2 lists results of the steady-state water balance, with long-term averages, peak groundwater flows and solute fluxes of total nitrogen and sulfur. For determining long-term averages of groundwater fluxes, monthly groundwater contour maps were generated for both floodplain aquifers, from May 2018 until July 2019. Two scenarios were considered - in scenario 1, the geometric mean of transmissivity estimates in the Tufa and Gravel aquifers, and an arithmetic mean for the Hillslope Aquifers, were taken as the basis for the aquifer transmissivity estimates; however, in scenario 2, higher estimates were considered. For the Hillslope Aquifer, transmissivities twice that of the arithmetic mean were assigned to aquifer material within the thick hillslope hollow colluvium. These values are comparable to the highest yielding hillslope monitoring wells. The transmissivity of the Tufa Aquifer was also increased by about a factor of four, and the study explicitly accounted for the channel of clean gravel, where transmissivity values are determined from two monitoring wells that are potentially screened in this channel $(1.2 \times$ $10^{-3} \mathrm{~m}^{2} / \mathrm{s}$ rather than the geometric mean of $1.3 \times 10^{-4} \mathrm{~m}^{2} / \mathrm{s}$ of the entire Gravel Aquifer).

With an annual groundwater recharge of approximately $200 \mathrm{~mm} /$ year, and a recharge area of $2.65 \mathrm{~km}^{2}$, the floodplain collects less than $1 \%(\sim 0.12 \mathrm{~L} / \mathrm{s})$ of the total hillslope recharge $(16.8 \mathrm{~L} / \mathrm{s})$ in scenario 1 , and approximately $2-4 \%$ in scenario 2 . Thus, this groundwater flux is collected within the colluvial aquifer material in the hillslope hollows and subsequently partitioned between the floodplain aquifers. Approximately 15 and $85 \%$ of the hillslope groundwater goes to the Tufa and Gravel aquifers, respectively. In both scenarios, it is estimated that the hillslope infiltrate increases the along-valley groundwater discharge within the Tufa and Gravel aquifers by approximately $100-150 \%$, from $\mathrm{CP}_{\text {upstr }}$ to $\mathrm{CP}_{\mathrm{dwnstr}}$. In scenario 1, groundwater discharge in the Gravel Aquifer is about three to four times larger than that in the Tufa Aquifer, whereas this increases to a factor of six in scenario 2 when accounting for the gravel channel.

Under these conceptual assumptions, the water balance calculations suggest that the recharge area contributing to the local floodplain groundwater system is very small in comparison to the entire southern hillslope between $\mathrm{CP}_{\text {upstr }}$ to $\mathrm{CP}_{\mathrm{dwnstr}}$, and the majority of hillslope infiltrate completely bypasses the floodplain groundwater system. It is therefore concluded that the bulk hydraulic properties associated to the predominantly fine-grained hillslope and floodplain sediments do not facilitate enough groundwater flow to drain the southern hillslope recharge area and the floodplain would rather act as a barrier to cross-valley groundwater flow than as a conduit.

As seen in the comparison between scenarios 1 and 2, the groundwater fluxes are highly sensitive to the geometric and hydraulic properties of the aquifer materials. The uncertainty of such properties is extremely high in these characteristically 
Table 2 Water and solute balance in the floodplain aquifer

\begin{tabular}{|c|c|c|c|c|c|c|}
\hline Aquifer & Aquifer transmissivity $\left[\mathrm{m}^{2} / \mathrm{s}\right]$ & Control plane & $\begin{array}{l}\text { Long-term average } \\
\text { water flux }[\mathrm{L} / \mathrm{s}]\end{array}$ & $\begin{array}{l}\text { Peak water } \\
\text { flux }[\mathrm{L} / \mathrm{s}]\end{array}$ & $\begin{array}{l}\text { Total sulfur } \\
\text { load }[\mathrm{kg} / \text { year }]\end{array}$ & $\begin{array}{l}\text { Total nitrogen } \\
\text { load }[\mathrm{kg} / \text { year }]\end{array}$ \\
\hline \multicolumn{7}{|c|}{ Scenario 1: geometric means of aquifer transmissivities } \\
\hline Hillslope & $7.6 \times 10^{-5}$ & $\mathrm{CP}_{\text {hslp }}$ & 0.12 & 0.20 & 24.2 & 3.42 \\
\hline \multirow[t]{2}{*}{ Tufa } & $1.7 \times 10^{-5}$ & $\mathrm{CP}_{\text {upstr }}$ & 0.02 & 0.025 & 65.3 & 1.29 \\
\hline & & $\mathrm{CP}_{\text {dwnstr }}$ & 0.04 & 0.05 & 26.7 & 3.13 \\
\hline \multirow[t]{2}{*}{ Gravel } & $1.3 \times 10^{-4}$ & $\mathrm{CP}_{\text {upstr }}$ & 0.06 & 0.065 & 190 & 1.92 \\
\hline & & $\mathrm{CP}_{\text {dwnstr }}$ & 0.16 & 0.165 & 111 & 10.8 \\
\hline \multicolumn{7}{|c|}{ Scenario 2: high transmissivity features included } \\
\hline Hillslope/Hillslope hollows & $7.6 \times 10^{-5} / 1.5 \times 10^{-4}$ & $\mathrm{CP}_{\text {hslp }}$ & 0.59 & 0.96 & 68 & 9.64 \\
\hline \multirow[t]{2}{*}{ Tufa } & $6.7 \times 10^{-5}$ & $\mathrm{CP}_{\text {upstr }}$ & 0.07 & 0.10 & 199 & 3.93 \\
\hline & & $\mathrm{CP}_{\text {dwnstr }}$ & 0.14 & 0.21 & 81.3 & 9.51 \\
\hline \multirow[t]{2}{*}{ Gravel/gravel channel } & $1.0 \times 10^{-4} / 1.2 \times 10^{-3}$ & $\mathrm{CP}_{\text {upstr }}$ & 0.42 & 0.45 & 2,607 & 12.1 \\
\hline & & $\mathrm{CP}_{\text {dwnstr }}$ & 0.80 & 0.86 & 902 & 10.9 \\
\hline
\end{tabular}

heterogeneous geologic settings in temperate climates. Increasing the effective hydraulic conductivity and connectivity of the hillslope hollow colluvium and the downstream gravel channel by a factor of three to four would result in far different interpretations on the hydraulic behavior of the floodplain, thus its biogeochemical functioning.

\section{Dynamics of hillslope groundwater discharge}

Peak groundwater discharge estimates presented in Table 2 highlight the increased discharge dynamics within the Hillslope Aquifer as compared to the floodplain aquifers. Groundwater discharge from the hillslope increased as much as $0.37 \mathrm{~L} / \mathrm{s}$ as compared to $\sim 0.05 \mathrm{~L} / \mathrm{s}$ in the floodplain. These hillslope dynamics are observed both in seasonal groundwater fluctuations and from single rainfall events (Fig. 7). Since the floodplain aquifers do not accommodate the extra flux, the springs and drainage channels running parallel to the hillslope-floodplain boundary (Fig. 2) must act as "release valves" and receive a substantial fraction of subsurface hillslope runoff during hydrological events.

Table 3 presents surface water and groundwater fluxes from a rainfall event on March 13, 2019. Over the course of a day and a half, there was $10 \mathrm{~mm}$ of rainfall, followed by a 3-week dry period. Surface-water fluxes are derived from river stage measurements in v-notch weirs within the drainage channels, as outlined in Fig. 10b, while groundwater fluxes are calculated from the groundwater contour maps. Pre- and post-rainfall water fluxes show the increase in discharges immediately after rainfall, which are summed up over a subsequent 14-day period, to estimate the approximate amount of additional water coming from the rainfall event. The increase in discharge within the drainage channels is substantially higher than the groundwater flux increase, indicating that a significant amount of recharge from the rain event likely travels rapidly to the drainage channels as interflow. Increases in hillslope groundwater fluxes were twice as large as in the two floodplain aquifers combined, so it is believed that this additional groundwater flux is captured by the hillslope spring. Though the hillslope spring is providing an important release valve for excess hillslope groundwater, the total amount of water which accumulated over the days following the event, only accounts for approximately $15 \%\left(960 \mathrm{~m}^{3}\right)$ of the total hillslope recharge $\left(6,600 \mathrm{~m}^{3}\right)$ from that rain event. The discharge estimates from the drainage channel weirs are uncertain. However due to the large discrepancy between groundwater and surface-water fluxes, as well as surface-water fluxes and hillslope recharge, this measurement uncertainty does not impact the interpretation of the results.

The likely candidate for this substantial unaccounted-for hillslope recharge could be a weathered bedrock aquifer, which may discharge further downstream to the gravel channel, or possibly to the neighboring river catchment as interbasin groundwater flow.

\section{Fate of redox-sensitive solutes}

The water recharging along the hillslopes, or from the Ammer River, contains elevated levels of dissolved oxygen and nitrate, whereas the groundwater in the Tufa Aquifer lacks these electron acceptors altogether. This implies that the total electron-acceptor flux from the southern hillslope to the Tufa Aquifer is reduced. It is not possible to make any statements about the reduction kinetics, as the transition from the observation wells on the hillslope to those in the Tufa Aquifer is binary. However, assessing the kinetics is futile if the entire flux is converted anyway. While the Tufa Aquifer appears a 
Table 3 Fluxes of surface water $\left(Q_{\mathrm{s}}\right)$ and groundwater $\left(Q_{\mathrm{g}}\right)$ from a rainfall event on 13 March 2019

\begin{tabular}{|c|c|c|c|}
\hline Water body/aquifer & Pre-rainfall water flux $[\mathrm{L} / \mathrm{s}]$ & $\begin{array}{l}\text { Peak rainfall } \\
\text { water flux }[\mathrm{L} / \mathrm{s}]\end{array}$ & $\begin{array}{l}\text { Cumulative discharge } \\
\text { over } 14 \text { days }\left[\mathrm{m}^{3}\right]\end{array}$ \\
\hline \multicolumn{4}{|l|}{ Surface water } \\
\hline $\begin{array}{l}\text { Hillslope spring } \\
\left(Q_{\mathrm{s} \text { CPhlsp }}\right)\end{array}$ & $1.1^{\mathrm{a}}$ & $3.0^{\mathrm{a}}$ & $960^{\mathrm{a}}$ \\
\hline $\begin{array}{l}\text { Drainage channel - } \\
\text { upstream }\left(Q_{\mathrm{s}, \mathrm{CP} u p s t r}\right)\end{array}$ & $2.8^{\mathrm{a}}$ & $7.2^{\mathrm{a}}$ & $830^{\mathrm{a}}$ \\
\hline $\begin{array}{l}\text { Drainage channel - } \\
\text { downstream }\left(Q_{\mathrm{s}, \mathrm{CPdwnstr}}\right)\end{array}$ & $5.1^{\mathrm{a}}$ & $10.3^{\mathrm{a}}$ & $1,200^{\mathrm{a}}$ \\
\hline \multicolumn{4}{|l|}{ Groundwater - scenario 2} \\
\hline $\begin{array}{l}\text { Hillslope } \\
\left(Q_{\mathrm{g}, \text { CPupstr }}\right)\end{array}$ & 0.52 & 0.70 & $203^{\mathrm{b}}$ \\
\hline $\begin{array}{l}\text { Tufa } \\
\left(Q_{\mathrm{g}, \mathrm{CPupstr}}-Q_{\mathrm{g}, \mathrm{CPdwnstr}}\right)\end{array}$ & 0.08 & 0.10 & $23^{\mathrm{b}}$ \\
\hline $\begin{array}{l}\text { Gravel } \\
\left(Q_{\mathrm{g}, \mathrm{CPupstr}}-Q_{\mathrm{g}, \mathrm{CPdwnstr}}\right)\end{array}$ & 0.40 & 0.47 & $67^{\mathrm{b}}$ \\
\hline \multicolumn{4}{|c|}{$\begin{array}{l}\text { Hillslope recharge }\left[\mathrm{m}^{3}\right]=\text { rainfall }[\mathrm{mm}] \times \text { recharge area }\left[\mathrm{km}^{2}\right] \times \text { recharge fraction } \\
=10 \mathrm{~mm} \times 2.65 \mathrm{~km}^{2} \times 0.25 \sim 6,600 \mathrm{~m}^{3} \text { of hillslope recharge }\end{array}$} \\
\hline
\end{tabular}

biogeochemical hotspot, its relevance for the large-scale electron-acceptor balance is limited, because there is hardly any water discharge passing through the Tufa Aquifer. The combination of highly reducing conditions at low flow-through is fairly typical for many sedimentary systems. If there had been more flow through these deposits in the last 2,000 years, the high electron-donor content of the matrix may have already reacted with the incoming flux of dissolved oxygen.

The Gravel Aquifer is less reducing. However, there is no indication that oxidized water from the southern hillslope is transferred to the oxidized eastern part of the Gravel aquifer without passing a reducing zone. It is believed that the entire flux of dissolved electron acceptors entering the floodplain sediments is reduced, regardless of influx occurring into the Tufa or Gravel aquifers. As stated previously, the prevalence of oxidizing conditions at the downstream end of the Gravel Aquifer indicates the relevance of the postulated clean-gravel channel underneath the clayey gravel. That is, also large parts of the reducing sections in the Gravel Aquifer are bypassed by the major groundwater flux.

It is not possible to make any statements on whether dissolved ammonium found in reduced groundwater originates from nitrate inputs via direct nitrogen reduction to ammonium or from natural organic matter decomposition via ammonification. Also, setting up a sulfur balance is difficult (Table 2). Not all sulfate is reduced to sulfide species, but wherever there is direct contact to bedrock of the Grabfeld formation there is a chance of new sulfate inputs from subrosion of gypsum.

\section{Conclusions}

A bias towards research on field sites where the floodplain acts as a conduit to groundwater flows limits the generalized statements made on the hydrogeological and biogeochemical functioning of a floodplain. Amongst hydrogeologists, there is a bias towards research on larger floodplains of higher-order river systems with wide, thick and transmissive alluvial aquifers because they can be exploited for drinking-water production and irrigation. Many of the near-surface hydrogeological and hydrogeophysical investigation techniques have been catered towards these types of sedimentary settings. With such permeable aquifer material, the floodplain groundwater fluxes are significant and facilitate a strong connection between the landscape and the draining surface-water body.

The catchment hydrology community is biased towards research on headwater sites, especially those where bedrock is significantly less permeable than the upper soil mantle. These sites are treated as closed hydrologic systems, where the draining streams act as the integrators of water flows, and topographic indices are used to characterize the hydrology of landscape elements. This conceptualization implicitly requires that floodplains must be conduits for subsurface water flow, and thus, their hydraulic and biogeochemical properties are critical for the timing and magnitude of streamflow generation, and the resulting streamflow chemistry.

Due to the high content of fines and organic material, and their location within the hydrological system, biogeochemists 
are biased towards research on highly reactive floodplains sites. With these regions of enhanced reactivity, biogeochemists typically assign floodplains a critical catchment-scale filter function against agricultural infiltrate. This requires that the majority of water is forced to pass through the floodplain material on its way to the stream, thus acting as a conduit for groundwater flow; however, that is often not considered by biogeochemists.

In contrast to many studies on floodplain hydrologic functioning, the predominance of lower-permeability hillslope and floodplain aquifer material suggests that temperate floodplains have the potential to act as significant barriers to groundwater flow. This study's characterization of the Ammer floodplain, a temperate analog, provides evidence for this hydrological ambiguity: (1) the local floodplain groundwater system shows a strong connection to the hillslope, and very weak correlation to the river stage fluctuations, unless in the direct vicinity of the river; (2) groundwater collects the net precipitation on the southern hillslope; however, the generally fine-grained hillslope colluvium and floodplain alluvium acts as a barrier to groundwater flow, suggesting a large proportion of groundwater may bypass the floodplain via intermediate groundwater flow systems; (3) springs and drainage channels along the hillslope-floodplain transition provide the necessary release valve for excess hillslope groundwater discharge, not collected by the floodplain.

This study's interpretation of the floodplain functioning is directly linked to the presence or absence of major hydrogeological features, and their associated hydraulic and geometric parameters. A large discrepancy is revealed, between the estimated recharge in the catchment and the observed groundwater and surface water fluxes. This discrepancy could result from conceptual model uncertainty (e.g., presence of a weathered-bedrock aquifer) and/or the hydraulic and geometric parameter uncertainty of the major hydrogeological features investigated in this study (e.g., the gravel channel and the hillslope hollows). These limitations motivate the authors' future work. First, to address the conceptual model uncertainty, the plan is to take a step back and use generic numerical models to systematically determine the hydrological relevance of different surface and subsurface features. This would have the added benefit of determining dimensionless geometric and hydraulic parameters that control the system behavior, and of allowing for more generalized statements to be made on floodplain functioning. Validating the outcomes of such modeling exercises will require a step forward in hydrogeological and hydrogeophysical characterization techniques in such temperate fine-grained settings, sites often neglected by the research community at large.

Acknowledgements We thank N. Günes, M. Dersch, M. Jantz, A. Schoßland, H. Kotas, and T. Siller for field support, and Dr. U. Werban for coordination of direct-push field activities. Also, we thank Ó. Jiménez-Fernández and Dr. K. Osenbrück for providing the gauging data from the floodplain drainage channels, and the associated insightful discussion. Finally, we thank the reviewers Brighid É. Ó Dochartaigh and Donald S. Sweetkind for their helpful comments on the paper.

The data are available on a repository of the University of Tübingen: http:/hdl.handle.net/10900.1/80c042ec-ff39-4eea-8f17-38e725b90841

Funding information Open Access funding provided by Projekt DEAL. This study was funded by the Collaborative Research Center 1253 "CAMPOS-Catchments as Reactors", project P3 "Structural Controls of the Hydrological Functioning of a Floodplain" funded by the German Research Foundation (DFG, Grant Agreement SFB 1253/1 2017).

Open Access This article is licensed under a Creative Commons Attribution 4.0 International License, which permits use, sharing, adaptation, distribution and reproduction in any medium or format, as long as you give appropriate credit to the original author(s) and the source, provide a link to the Creative Commons licence, and indicate if changes were made. The images or other third party material in this article are included in the article's Creative Commons licence, unless indicated otherwise in a credit line to the material. If material is not included in the article's Creative Commons licence and your intended use is not permitted by statutory regulation or exceeds the permitted use, you will need to obtain permission directly from the copyright holder. To view a copy of this licence, visit http://creativecommons.org/licenses/by/4.0/.

\section{References}

Bloomfield JP, Bricker SH, Newell AJ (2011) Some relationships between lithology, basin form and hydrology: a case study from the Thames basin, UK. Hydrol Process 25:2518-2530. https://doi.org/ 10.1002/hyp. 8024

Bouwer H, Rice RC (1976) A slug test for determining hydraulic conductivity of unconfined aquifers with completely or partially penetrating wells. Water Resour Res 12:423-428. https://doi.org/10. 1029/WR012i003p00423

Brantley SL, Lebedeva MI, Balashov VN, Singha K, Sullivan PL, Stinchcomb G (2017) Toward a conceptual model relating chemical reaction fronts to water flow paths in hills. Geomorphology 277: 100-117. https://doi.org/10.1016/J.GEOMORPH.2016.09.027

Brown A, Toms P, Carey C, Rhodes E (2013) Geomorphology of the Anthropocene: time-transgressive discontinuities of human-induced alluviation. Anthropocene 1:3-13. https://doi.org/10.1016/J. ANCENE.2013.06.002

Brown AG, Lespez L, Sear DA, Macaire J-J, Houben P, Klimek K, Brazier RE, Van Oost K, Pears B (2018) Natural vs anthropogenic streams in Europe: history, ecology and implications for restoration, river-rewilding and riverine ecosystem services. Earth-Sci Rev 180: 185-205. https://doi.org/10.1016/J.EARSCIREV.2018.02.001

Brunner P, Cook PG, Simmons CT (2009) Hydrogeologic controls on disconnection between surface water and groundwater. Water Resour Res 45. https://doi.org/10.1029/2008WR006953

Burt TP, Pinay G (2005) Linking hydrology and biogeochemistry in complex landscapes. Prog Phys Geogr Earth Environ 29:297-316. https://doi.org/10.1191/0309133305pp450ra

Burt TP, Matchett LS, Goulding KWT, Webster CP, Haycock NE (1999) Denitrification in riparian buffer zones: the role of floodplain hydrology. Hydrol Process 13:1451-1463. https://doi.org/10.1002/ (SICI)1099-1085(199907)13:10<1451::AID-HYP822>3.0.CO;2$\mathrm{W}$

Burt TP, Pinay G, Matheson FE, Haycock NE, Butturini A, Clement JC, Danielescu S, Dowrick DJ, Hefting MM, Hillbricht-Ilkowska A, 
Maitre V (2002) Water table fluctuations in the riparian zone: comparative results from a pan-European experiment. J Hydrol 265: 129-148. https://doi.org/10.1016/S0022-1694(02)00102-6

Butler JJ Jr (1998) The design, performance, and analysis of slug tests. Lewis, New York

Buttle JM (1994) Isotope hydrograph separations and rapid delivery of pre-event water from drainage basins. Prog Phys Geogr Earth Environ 18:16-41. https://doi.org/10.1177/030913339401800102

Clément J-C, Aquilina L, Bour O, Plaine K, Burt TP, Pinay G (2003) Hydrological flowpaths and nitrate removal rates within a riparian floodplain along a fourth-order stream in Brittany (France). Hydrol Process 17:1177-1195. https://doi.org/10.1002/hyp.1192

Collins PEF, Worsley P, Keith-Lucas DM, Fenwick IM (2006) Floodplain environmental change during the younger Dryas and Holocene in Northwest Europe: insights from the lower Kennet Valley, south Central England. Palaeogeogr Palaeoclimatol Palaeoecol 233:113-133. https://doi.org/10.1016/j.palaeo.2005.09. 014

Dabkowski J (2020) The late-Holocene tufa decline in Europe: myth or reality? Quat Sci Rev 230:106-141. https://doi.org/10.1016/J. QUASCIREV.2019.106141

Devia GK, Ganasri BP (2015) A review on hydrological models. Aquat Procedia 4:1001-1007. https://doi.org/10.1016/J.AQPRO.2015.02. 126

Devito KJ, Fitzgerald D, Hill AR, Aravena R (2000) Nitrate dynamics in relation to lithology and hydrologic flow path in a river riparian zone. J Environ Qual 29:1075. https://doi.org/10.2134/jeq2000. $00472425002900040007 x$

Devito K, Creed I, Gan T, Mendoza C, Petrone R, Silins U, Smerdon B (2005) A framework for broad-scale classification of hydrologic response units on the boreal plain: is topography the last thing to consider? Hydrol Process 19:1705-1714. https://doi.org/10.1002/ hyp. 5881

Dramis F, Materazzi M, Cilla G (1999) Influence of climatic changes on freshwater travertine deposition: a new hypothesis. Phys Chem Earth, Part A 24:893-897. https://doi.org/10.1016/S1464-1895(99) 00132-5

Duval TP, Hill AR (2006) Influence of stream bank seepage during lowflow conditions on riparian zone hydrology. Water Resour Res 42. https://doi.org/10.1029/2006WR004861

Duval TP, Waddington JM (2018) Effect of hydrogeomorphic setting on calcareous fen hydrology. Hydrol Process 32:1695-1708. https:// doi.org/10.1002/hyp.11625

Fan Y (2019) Are catchments leaky? WIREs Water 6:e1386. https://doi. org/10.1002/wat2.1386

Frauendiener R (1963) Das Ammertal mit Land und Leuten im Wandel der Zeiten [The Ammer Valley With the country and its people through the ages]. Tübinger Chronik, Tübingen, Germany

Geyer OF, Gwinner MP (2011) Geologie von Baden-Württemberg [Geology of Baden- Württemberg], 5th edn. Schweizerbart, Stuttgart, Germany

Gibbard P, Lewin J (2002) Climate and related controls on interglacial fluvial sedimentation in lowland Britain. Sediment Geol 151:187210. https://doi.org/10.1016/S0037-0738(01)00253-6

Gilvear DJ, Sadler PJK, Tellam JH, Lloyd JW (1997) Surface water process and groundwater flow within a hydrologically complex floodplain wetland, Norfolk broads, U.K. Hydrol Earth Syst Sci Discuss 1:115-135

Grathwohl P, Rügner H, Wöhling T, Osenbrück K, Schwientek M, Gayler S, Wollschläger U, Selle B, Pause M, Delfs J-O, Grzeschik M, Weller U, Ivanov M, Cirpka OA, Maier U, Kuch B, Nowak W, Wulfmeyer V, Warrach-Sagi K, Streck T, Attinger S, Bilke L, Dietrich P, Fleckenstein JH, Kalbacher T, Kolditz O, Rink K, Samaniego L, Vogel H-J, Werban U, Teutsch G (2013) Catchments as reactors: a comprehensive approach for water fluxes and solute turnover. Environ Earth Sci 69:317-333. https://doi.org/ 10.1007/s12665-013-2281-7

Günther T, Rücker C, Spitzer K (2006) Three-dimensional modelling and inversion of DC resistivity data incorporating topography: II. inversion. Geophys J Int 166:506-517. https://doi.org/10.1111/j.1365246X.2006.03011.X

Hagedorn J, Rother N (1992) Holocene floodplain evolution of small rivers in the uplands of Lower Saxony, Germany. Geomorphology 4:423-432. https://doi.org/10.1016/0169-555X(92)90036-N

Hale VC, McDonnell JJ (2016) Effect of bedrock permeability on stream base flow mean transit time scaling relations: 1 . a multiscale catchment intercomparison. Water Resour Res 52:1358-1374. https://doi. org/10.1002/2014wr016124

Hale VC, McDonnell JJ, Stewart MK, Solomon DK, Doolitte J, Ice GG, Pack RT (2016) Effect of bedrock permeability on stream base flow mean transit time scaling relationships: 2 . process study of storage and release. Water Resour Res 52:1375-1397. https://doi.org/10. 1002/2015wr017660

Haycock NE, Burt TP, Goulding KWT, Pinay G (1997) Buffer zones: their processes and potential in water protection. Int. Conf. on Buffer Zones, September 1996, Quest Environmental, Greenwood Village, CO, pp 21-32

Hill AR (1990) Ground water flow paths in relation to nitrogen chemistry in the near-stream zone. Hydrobiologia 206:39-52. https://doi.org/ 10.1007/BF00018968

Hill AR (2019) Groundwater nitrate removal in riparian buffer zones: a review of research progress in the past 20 years. Biogeochemistry 143:347-369. https://doi.org/10.1007/s10533-019-00566-5

Hill AR, Vidon PGF, Langat J (2004) Denitrification potential in relation to lithology in five headwater riparian zones. J Environ Qual 33:911. https://doi.org/10.2134/jeq2004.0911

Houben P (2003) Spatio-temporally variable response of fluvial systems to Late Pleistocene climate change: a case study from central Germany. Quat Sci Rev 22:2125-2140. https://doi.org/10.1016/ S0277-3791(03)00181-1

Hyder Z, Butler JJ Jr, McElwee CD, Liu W (1994) Slug tests in partially penetrating wells. Water Resour Res 30:2945-2957. https://doi.org/ 10.1029/94WR01670

Jacobs TC, Gilliam JW (1985) Riparian losses of nitrate from agricultural drainage waters. J Environ Qual 14:472-478. https://doi.org/10. 2134/jeq1985.00472425001400040004x

Jencso KG, McGlynn BL (2011) Hierarchical controls on runoff generation: topographically driven hydrologic connectivity, geology, and vegetation. Water Resour Res 47:W11527. https://doi.org/10.1029/ 2011WR010666

Jung M, Burt TP, Bates PD (2004) Toward a conceptual model of floodplain water table response. Water Resour Res 40. https://doi.org/10. 1029/2003WR002619

Karan S, Engesgaard P, Looms MC, Laier T, Kazmierczak J (2013) Groundwater flow and mixing in a wetland-stream system: field study and numerical modeling. J Hydrol 488:73-83. https://doi. org/10.1016/J.JHYDROL.2013.02.030

Kim H, Høyer A-S, Jakobsen R, Thorling L, Aamand J, Maurya PK, Christiansen AV, Hansen B (2019) 3D characterization of the subsurface redox architecture in complex geological settings. Sci Total Environ 693:133583. https://doi.org/10.1016/J.SCITOTENV.2019. 133583

Kirchner JW (2003) A double paradox in catchment hydrology and geochemistry. Hydrol Process 17:871-874. https://doi.org/10.1002/ hyp. 5108

Klingler S, Leven C, Cirpka OA, Dietrich P (2020) Anomaly effectdriven optimization of direct-current geoelectric mapping surveys in large areas. J Appl Geophys 176:104002. https://doi.org/10. 1016/J.JAPPGEO.2020.104002

Kolbe T, de Dreuzy J-R, Abbott BW, Aquilina L, Babey T, Green CT, Fleckenstein JH, Labasque T, Laverman AM, Marçais J, Peiffer S, 
Thomas Z, Pinay G (2019) Stratification of reactivity determines nitrate removal in groundwater. Proc Natl Acad Sci U S A 116: 2494-2499. https://doi.org/10.1073/pnas.1816892116

Kortunov E (2018) Reactive transport and long-term redox evolution at the catchment scale. PhD Thesis, Univ. Tübingen, Germany. https:// doi.org/10.15496/publikation-25162

Landesamt für Geoinformation und Landentwicklung (LGL) (2009) Digitales Geländemodell, 10 m-Gitter, DGM10. http://www.lglbw.de. Accessed 20 Jul 2017

Landesamt für Geologie, Rohstoffe und Bergbau (LGRB) (2012) Geologische Karte von Baden-Württemberg 1:50 000 (GeoLa) 1: 50,000. www.lgrb-bw.de. Accessed 20 Jul 2017

Landesanstalt für Umwelt Baden-Württemberg (LUBW) (2020) https:// udo.lubw.baden-wuerttemberg.de. Accessed 01 Jun 2020

Landwirtschaftliches Technologiezentrum (LTZ) (2020) Agrarmeteorologie Baden-Württemberg [Weather data]. https:// www.wetter-bw.de. Accessed 01 Jun 2020

Larkin RG, Sharp JM (1992) On the relationship between river-basin geomorphology, aquifer hydraulics, and ground-water flow direction in alluvial aquifers. GSA Bull 104:1608-1620. https://doi.org/ 10.1130/0016-7606(1992)104<1608:OTRBRB > 2.3.CO;2

Lespez L, Clet-Pellerin M, Limondin-Lozouet N, Pastre J-F, Fontugne M, Marcigny C (2008) Fluvial system evolution and environmental changes during the Holocene in the Mue Valley (western France). Geomorphology 98:55-70. https://doi.org/10.1016/j.geomorph. 2007.02.029

Ó Dochartaigh BÉ, NAL A, Peskett L, AM MD, Black AR, Auton CA, Merritt JE, Gooddy DC, Bonell M (2019) Geological structure as a control on floodplain groundwater dynamics. Hydrogeol J 27:703716. https://doi.org/10.1007/s10040-018-1885-0

Pazzaglia F, Barchi MR, Buratti N, Cherin M, Pandolfi L, Ricci M (2013) Pleistocene calcareous tufa from the Ellera basin (Umbria, central Italy) as a key for an integrated paleoenvironmental and tectonic reconstruction. Quat Int 292:59-70. https://doi.org/10.1016/J. QUAINT.2012.11.020

Pedley HM (1990) Classification and environmental models of cool freshwater tufas. Sediment Geol 68:143-154

Pfeiffer SM, Bahr JM, Beilfuss RD (2006) Identification of groundwater flowpaths and denitrification zones in a dynamic floodplain aquifier. J Hydrol 325:262-272. https://doi.org/10.1016/j.jhydrol.2005.10. 019

Pfister L, Martínez-Carreras N, Hissler C, Klaus J, Carrer GE, Stewart MK, McDonnell JJ (2017) Bedrock geology controls on catchment storage, mixing, and release: a comparative analysis of 16 nested catchments. Hydrol Process 31:1828-1845. https://doi.org/10.1002/ hyp. 11134

Pinder GF, Sauer SP (1971) Numerical simulation of flood wave modification due to Bank storage effects. Water Resour Res 7:63-70. https://doi.org/10.1029/WR007i001p00063
Rempe DM, Dietrich WE (2014) A bottom-up control on fresh-bedrock topography under landscapes. Proc Natl Acad Sci U S A 111:65766581. https://doi.org/10.1073/pnas.1404763111

Roe HM, Preece RC (2011) Incised palaeo-channels of the late middle Pleistocene Thames: age, origins and implications for fluvial palaeogeography and sea-level reconstruction in the southern North Sea basin. Quat Sci Rev 30:2498-2519. https://doi.org/10. 1016/J.QUASCIREV.2011.04.007

Schilling KE, Jacobson P (2012) Spatial relations of topography, lithology and water quality in a large river floodplain. River Res Appl 28: 1417-1427. https://doi.org/10.1002/rra.1531

Schwientek M, Osenbrück K, Fleischer M (2013) Investigating hydrological drivers of nitrate export dynamics in two agricultural catchments in Germany using high-frequency data series. Environ Earth Sci 69:381-393. https://doi.org/10.1007/s12665-013-2322-2

Tesoriero AJ, Puckett LJ (2011) O2 reduction and denitrification rates in shallow aquifers. Water Resour Res 47:12522. https://doi.org/10. 1029/2011WR010471

Theis CV (1935) The relation between the lowering of the Piezometric surface and the rate and duration of discharge of a well using ground-water storage. EOS Trans Am Geophys Union 16:519524. https://doi.org/10.1029/TR016i002p00519

Vidon P, Allan C, Burns D, Duval TP, Gurwick N, Inamdar S, Lowrance R, Okay J, Scott D, Sebestyen S, Low-Rance R (2010) Hot spots and hot moments in riparian zones: potential for improved water quality management 1. JAWRA 278. J Am Water Resour Assoc 46:278298

Vidon PG, Welsh MK, Hassanzadeh YT (2019) Twenty years of riparian zone research (1997-2017): where to next? J Environ Qual 48:248. https://doi.org/10.2134/jeq2018.01.0009

Ward JH (1963) Hierarchical grouping to optimize an objective function. J Am Stat Assoc 58(301):236-244

Yabusaki SB, Wilkins MJ, Fang Y, Williams KH, Arora B, Bargar J, Beller HR, Bouskill NJ, Brodie EL, Christensen JN, Conrad ME, Danczak RE, King E, Soltanian MR, Spycher NF, Steefel CI, Tokunaga TK, Versteeg R, Waichler SR, Wainwright HM (2017) Water table dynamics and biogeochemical cycling in a shallow, variably-saturated floodplain. Environ Sci Technol 51:3307-3317. https://doi.org/10.1021/acs.est.6b04873

Žák K, Ložek V, Kadlec J, Hladíková J, Cílek V (2002) Climate-induced changes in Holocene calcareous tufa formations, Bohemian karst, Czech Republic. Quat Int 91:137-152. https://doi.org/10.1016/ S1040-6182(01)00107-0

Publisher's note Springer Nature remains neutral with regard to jurisdictional claims in published maps and institutional affiliations. 